\title{
Application of lithogeochemistry in the assessment of nickel-sulphide potential in komatiite belts from northern Finland and Norway
}

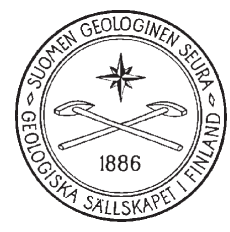

\author{
G.J. Heggie ${ }^{1}$, S.J. Barnes ${ }^{2}$ and M.L. Fiorentini ${ }^{1 *}$ \\ ${ }^{1}$ Centre for Exploration Targeting, School of Earth and Environment, \\ Australian Research Council Centre of Excellence for Core to Crust Fluid Systems, \\ The University of Western Australia, 35 Stirling Highway, Crawley, WA 6009, Australia \\ ${ }^{2}$ CSIRO Earth Science and Resource Engineering, Australian Resource Research Centre, \\ PO. Box 1130, Bentley, WA 6102, Australia
}

\begin{abstract}
This study tests the application of chalcophile elements such as nickel, copper and the platinum-group elements as indicators of nickel-sulphide prospectivity in komatiites from terranes of the Karelian Craton in northern Finland and Norway. Major element abundances reflect volcanic processes associated with the emplacement dynamics of ultramafic lavas, whereas the variable chalcophile element concentrations record the ore-forming process, mainly as an anomalous metal depletion and enrichment relative to the calculated background. Geochemical data from this study indicate that Paleoproterozoic komatiites in the Pulju Greenstone Belts and Archean komatiites in the Enontekiö area are prospective for nickel-sulphide mineralisation. Conversely, on the basis of the present dataset, ultramafic rocks from the Palaeoproterozoic Karasjok Greenstone Belt display lower prospectivity for nickel-sulphides, although potential exists if high-volume flow conduits and channels within the large volcanic flow field could be identified.
\end{abstract}

Keywords: nickel ores, sulfides, komatiite, chalcophile elements, ultramafics, lithogeochemistry, Paleoproterozoic, Archean, Finland, Norway

* Corresponding author email: marco.fiorentini@uwa.edu.au

Editorial handling: Igor Puchtel

\section{Introduction}

The search for komatiite-hosted nickel-sulphide systems is a challenge for exploration targeting, due to the small size of targets and the absence of easily recognisable alteration haloes that can enable small targets to be identified from sparse drilling. While some of these deposits are geophysical electromagnetic (EM) targets, many are not, and those that are EM targets are commonly camouflaged by 
the presence of neighbouring barren conductors. The result is that over the last few years, the discovery rate of new komatiite-hosted nickel-sulphide deposits worldwide has significantly decreased (Hronsky \& Schodde, 2006).

Lithogeochemistry has the capacity to increase the detectable footprint of komatiite-hosted nickelsulphides beyond the physical boundaries of the mineralised environment. Major element lithogeochemistry can assist in the identification of prospective volcanic facies (Barnes et al., 2004, 2007), while platinum group elements, due to their highly chalcophile nature and intimate association with the ore-forming process (Fiorentini et al., 2010), can be successfully utilised to assess whether komatiites reached sulphide saturation (Keays, 1982; Barnes et al. 1985; Lesher et al., 2001; Fiorentini et al., 2010). Barnes et al. (2013), Heggie (2010) and Heggie et al. (2012a, b) went further and indicated that the spatially constrained utilisation of chalcophile element lithogeochemistry can potentially be used as a vector towards komatiite-hosted nickelsulphides at a mine or prospect scale.

Mineralisation indicators are based on several chalcophile elements: $\mathrm{Ni}, \mathrm{Cu}$, and PGE (platinum [Pt], palladium [Pd], iridium [Ir], rhodium [Rh], and ruthenium $[\mathrm{Rh}]$ ). The chalcophile nature of the $\mathrm{PGE}, \mathrm{Ni}$ and $\mathrm{Cu}$ generates recognisable mineralisation signatures in systems that attain sulphide saturation and segregate immiscible sulphide liquid (Barnes et al., 1985; Lesher et al., 2001; Fiorentini et al., 2010; Heggie et al., 2012a, b). Enrichment and depletion anomalies can be identified in platinum group elements, representing the positive and negative residual anomalies from a calculated background baseline (Barnes et al., 2013; Heggie, 2010; Heggie et al., 2012a, b) that records komatiite crystallisation without sulphide accumulation or removal. Positive anomalies, interpreted as the result of presence of trace amounts of highly PGE enriched cumulus sulphides, are discernible in samples lacking any other evidence for the presence of a sulphide component, and define extensive haloes around mineralisation.

Fiorentini et al. $(2010,2011)$ and Heggie et al. (2012) documented background baseline PGE abundances, i.e. abundances in the absence of sulphide saturation, and PGE enrichment and depletion signatures for selected mineralised Barberton- and Munro-type komatiites from Western Australia. Although Barberton- and Munro-type komatiites display significant geochemical differences (Arndt et al., 2008), they nonetheless display similar chalcophile element background baselines (Heggie et al., 2012) when age-relate variability (Maier et al., 2009) is taken into account.

In this study, major and chalcophile element lithogeochemistry is applied to ultramafic units from the Karelian Craton in northern Finland and Norway, to assess the application of lithogeochemistry in terranes with complex tectonic histories, limited exposure and differing komatiite types. In the study area, Palaeoproterozoic komatiites display a Ti-enriched geochemical affinity referred to as Karasjok-type (Barnes and Often, 1990; Hanski et al., 2001).

\section{Regional Setting}

The Karelian Craton of northern Sweden, Finland and Norway is part of Fennoscandia, which represents the northern part of the East European Craton. Lithological, petrological, geochronological, potential field, deep seismic reflection and refraction, and geoelectric data are available for many parts of Fennoscandia (Vaasjoki et al., 2005). Consequently, it is an important region for tracing Precambrian evolution and understanding mineral systems that formed in the Early Earth (Lahtinen et al., 2009).

Fennoscandia comprises three major crustal domains. From SW-NE the domains include: the Palaeoproterozoic Svecofennian Province exposed in the SW of Sweden and Finland, the Archean Karelian Craton occupying northeastern Finland and northwestern Russia, and the Kola-Lapland Province covering the Kola Peninsula and northernmost Finland and Norway (Fig. 1). Lahtinen et al. (2009) provided a comprehensive review of the geological evolution of Fennoscandia, whereas Lahtinen et al (2005) recently reviewed the Palaeoproterozoic tectonic evolution of the Karelian 


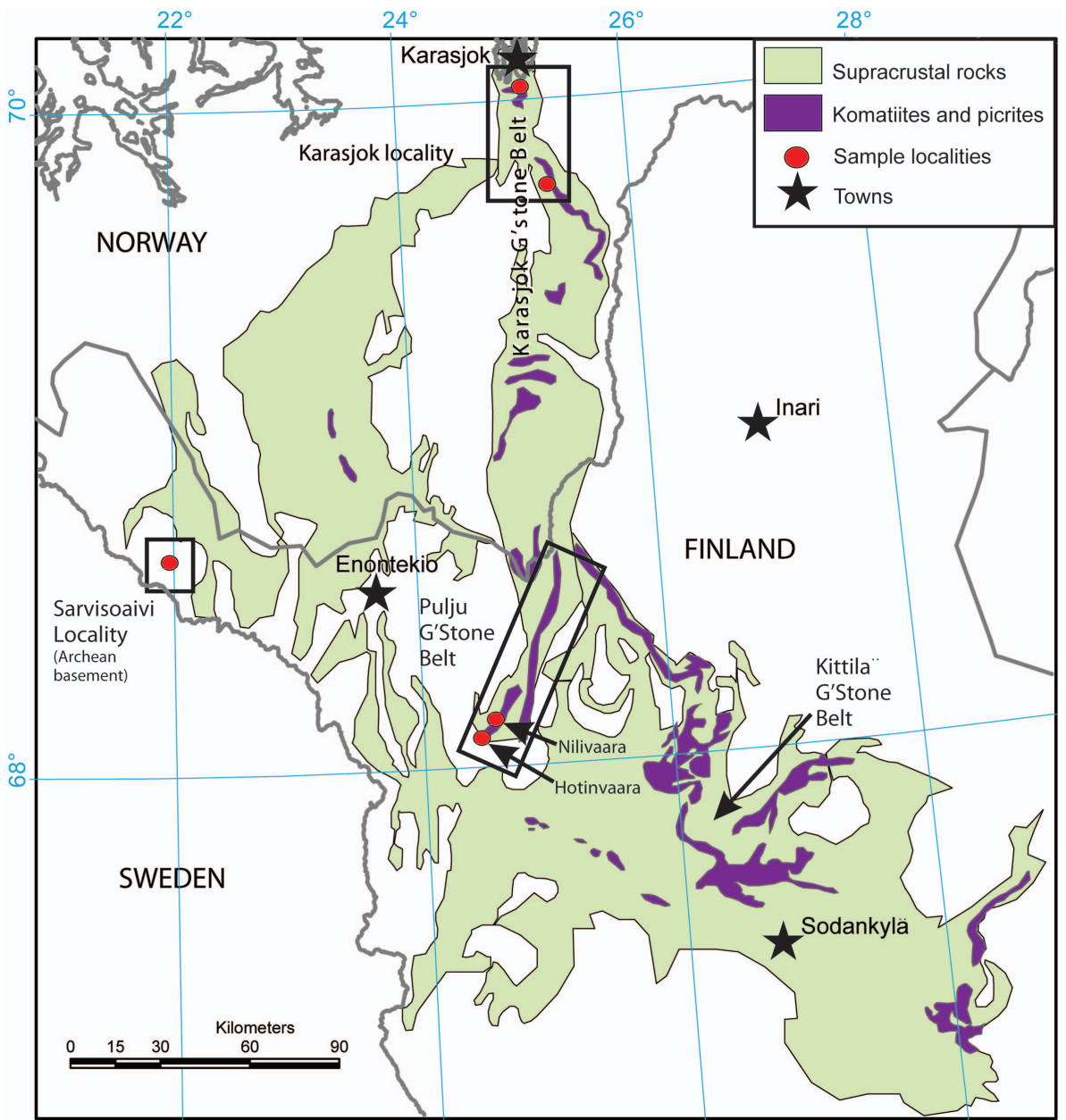

Fig. 1. Map of northern Sweden, Norway, Finland and northwestern Russia showing the distribution of the Paleoproterozoic Central Lapland Greenstone Belt (green), and associated komatiite and picritic rocks (blue). Sampling areas are delineated by boxes comprising the: Archean Sarvisoavi area, and Palaeoproterozoic Pulju and Karasjok Greenstone Belts.

Modified from Hanski et al. (2001). craton, which is regarded as the Archean nucleus of Fennoscandia. During the Palaeoproterozoic age, the Archean Karelian Craton acted as both a stable continental platform forming basement to the Palaeoproterozoic 2.5-1.9 Ga Central Lapland Greenstone Belt (Hanski \& Huhma, 2005) along the northeastern margin, and as a core for subsequent accretionary tectonics (Lehtonen et al., 1998; Hanski et al., 2001; Slabunov et al., 2006). Accretionary processes contributed to major continental growth in Fennoscandia during the Palaeoproterozoic, mainly from 2.1 to 1.8 Ga (Gaál \& Gorbatschev, 1987; Weihed et al., 2005; Lahtinen et al., 2009).

The Karelian Craton comprises lithological units as old as $3.1 \mathrm{Ga}$, but is dominated by younger 2.9-2.7 Ga granitoids and gneissic domains that intrude greenstone belts of similar age (Lobach-
Zhuchenko et al. 1993; Vaasjoki et al., 1993; Slabunov et al., 2006). The Karelian Craton also forms basement to younger Palaeoproterozoic (2.0-1.9 $\mathrm{Ga}$ greenstone sequences of the Central Lapland Greenstone Belt (Hanski \& Huhma, 2005; Fig. 1), which records Palaeoproterozoic depositional evolution for almost $600 \mathrm{Ma}$, beginning at -2450 Ma with the eruption of komatiitic to rhyolitic lavas on the Archean cratonic basement (Hanski \& Huhma, 2005). This magmatic phase also included emplacement of large layered mafic intrusions.

During the following 300-400 Ma, deposition of a thick, transgressive quartzite-dolomite-basaltpelite succession took place and was followed by komatiitic to picritic volcanism (Hanski \& Huhma, 2005). Mafic magmas intermittently formed layered sill-like intrusions within the sediments, most notably at $-2220 \mathrm{Ma}$ and $-2050 \mathrm{Ma}$. This 
prolonged extensional regime was interrupted by a collisional event, which led to thrusting of a $\sim 2000$ Ma slab of ancient oceanic lithosphere (the Kittilä Group) onto older cratonic rocks at $-1920 \mathrm{Ma}$ (Hanski \& Huhma, 2005). Roughly simultaneously, a juvenile calc-alkaline arc complex was formed farther north and was shortly followed by the upthrust of the Lapland granulite belt (Hanski \& Huhma, 2005). The supracrustal rock sequence in central Lapland was completed with the deposition of molasse-like, coarse clastic sediments in a forearc basin soon after $\sim 1880$ Ma synorogenic felsic plutonism and associated minor volcanism (Hanski \& Huhma, 2005).

The Karelian Craton contains both Archean and Palaeoproterozoic komatiites (Fig. 1). Archean komatiites are Munro-type (Slabunov et al., 2006), whereas Palaeoproterozoic units are Munro-type (Puchtel et al., 1997) and Karasjok-type to ferropicritic in composition (Barnes \& Often, 1990; Hanski et al., 2001; Gorbunov et al., 1985; Melezhik \& Sturt, 1994; Fiorentini et al., 2008). Nickel-sulphide mineralisation is associated with both age groups and geochemical types (Kurki \& Papunen, 1985; Saltikoff et al., 2006; Makkonen et al., 2009).

Archean komatiites (2.9-2.7 Ga) occurring within greenstone fragments of the Karelian Craton exhibit diverse litho-stratigraphic associations, ranging from komatiitic-tholeiitic-calc-alkaline volcanic rocks and sedimentary sequences, to dominant komatiite with intercalated felsic volcanic rocks, basalt, tuff and graphitic schist (e.g. Puchtel et al., 1998, 1999, 2007; Puchtel \& Humayun, 2000, 2001; Slabunov et al., 2006). Nickel-sulphide mineralisation is identified within komatiites of the Sumozero-Kenozero and Kuhmo-SuomussalmiTipasjärvi Greenstone Belts, and ultramafic (amphibolite) units within the Lieksa Complex and Enontekiö area (Papunen et al., 2009; Saltikoff et al., 2006; Makkonen et al., 2009).

Palaeoproterozoic komatiites (2.0-1.9 Ga) occur at different stratigraphic levels of the Central Lapland Greenstone Belt (Hanski \& Huhma, 2005; Fig. 1). The belt extends from northern Norway through Finnish Lapland to Russia, and comprises three sections: the Karasjok Greenstone Belt in the north (Norway), the Kittilä Greenstone Belt to the south (Finland) and the Pulju Greenstone Belt occurring in between (Fig. 1). These belts can be correlated with the Vetreny Greenstone Belt in the southeastern part of Fennoscandia in Russia based on similar stratigraphic position, lithology, and geochemistry (Hanski et al., 2001; Puchtel et al., 1997).

The volcano-sedimentary succession observed in the Palaeoproterozoic Central Lapland Greenstone Belt is variable from north to south. Stratigraphy is best documented within the Kittilä Greenstone Belt (Lehtonen et al., 1998; Hanski \& Huhma, 2005), while contrasting komatiitic lithological units are identified within the rift sequences of the Karasjok and Pulju Greenstone Belts (Papunen, 1998; Braathen \& Davidson, 2000). The main stratigraphy of the Kittilä Greenstone Belt is subdivided into the upper Lainio and Kumpu Groups and lower Salla, Onkamo, Sodankylä, Savukoski, and Kittilä Groups, separated by an unconformity (Hanski \& Huhma, 2005; Fig. 2).

Within the Kittilä Greenstone Belt, two geochemical units are identified within the stratigraphy beneath the unconformity. The lower ultramafic geochemical subdivision within the Onkamo Group comprises a komatiite-tholeiite sequence (approximately $250 \mathrm{~m}$ thick) that erupted upon both older intermediate-felsic volcanic rocks of the Salla Group and Archean basement (Lehtonen et al., 1998). The upper geochemical ultramafic unit extruded upon deeper water sediments of the Savukoski Group (Hanski et al., 2001), and comprises Karasjok-type (Ti-enriched) komatiites and picrites (Hanski et al., 2001; Barnes \& Often, 1990). Komatiitic units within the Kittilä Greenstone Belt are characterised by high $\mathrm{MgO}$ contents, variable light rare-earth element enrichment or depletion, heavy rare-earth depletion and middle rare earth and high field strength element enrichment (Hanski et al., 2001).

Extrusive ultramafic units within the Kittilä and correlative Karasjok Greenstone Belts are characterised by volcaniclastic rocks (agglomerates to tuffs) associated with massive and pillowed flows (Saverikko, 1985; Barnes \& Often, 1990; Gangopadhyay et al., 2006). Nickel-sulphide minerali- 
sation in the form of low-grade disseminated sulphides are identified at a number of prospects in the Central Lapland Greenstone Belt, with the two most significant being Hotinvaara (1.3 Mt at 0.4 wt $\% \mathrm{Ni}$ ) and Iso-Siettelöjoki (0.5 Mt at $0.29 \mathrm{wt} \%$ $\mathrm{Ni}$ ), both within the Pulju Greenstone Belt (Saltikoff et al., 2006; Makkonen et al., 2009).

\section{Sampling localities}

Sampling in this study was undertaken at three locations within sparsely outcropping ultramafic units (Fig. 1). Archean komatiite units were sampled within the Enontekiö area (Fig. 1: Papunen et al., 1977). Palaeoproterozoic komatiitic units were sampled within the Pulju Greenstone Belt and within the Karasjok Greenstone Belt (Figs. 1, 2). Field relationships are described in the literature for the sample locations within the Karasjok and Pulju Greenstone Belts (Papunen, 1998; Lehtonen et al., 1998; Barnes \& Often, 1990; Braathen \& Davidsen, 2000), and within the Enontekiö area (Papunen et al., 1977).

\subsection{Archean Komatiites (Enontekiö area)}

Archean komatiitic lithologies from the Enontekiö area (Sarvisoaivi locality) are associated with amphibolites, felsic to intermediate volcanic rocks, banded iron formation and sulphidic sediments (Papunen et al., 1977; Saltikoff et al., 2006). The

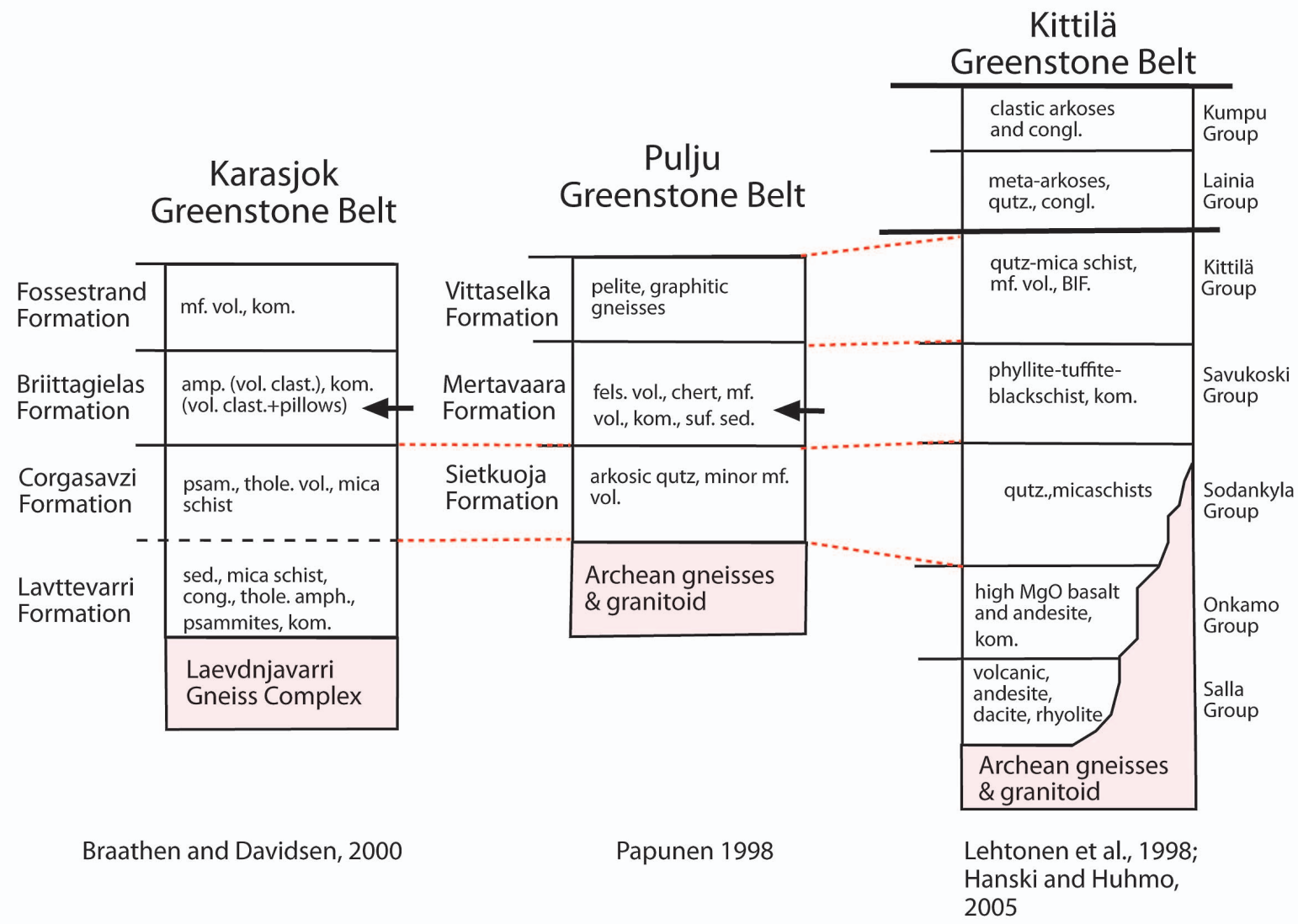

Fig. 2. Palaeoproterozoic stratigraphic sequences and correlations within the Central Lapland Greenstone Belt, comprising the Karasjok, Pulju and Kittilä Greenstone Belts. Arrows indicate formations sampled within the Karasjok and Pulju belts. Formations and Groups are identified with characteristic lithologies summarized: $\mathrm{mf}$. vol. = mafic volcanic, amp. = amphibolite, vol. clast. $=$ volcaniclastic, kom. $=$ komatiite, psam. $=$ psammite, thole . vol. $=$ tholeiitic volcanic, cong. $=$ conglomerate, fels. vol. $=$ felsic volcanic, suf. sed. $=$ sulphidic sediment, qutz. $=$ quartzite, $\mathrm{BIF}=$ banded iron formation . Compiled from Braathen and Davidson (2000); Papunen (1998); Lehtonen et al. (1998); Hanski and Huhma, 2005. Age determinations from Pihlaja and Manninen (1988), Hanski et al. (1997). 
komatiite samples were taken from thin differentiated flows and massive cumulate units (samples \#59 to 73; Table A1). Within the Enontekiö area, two zones of nickel-sulphide mineralisation are recognised: Ruossakero (5.5 Mt at $0.53 \% \mathrm{Ni}$ ) and Sarvisoaivi (0.7 Mt at $0.40 \%$ Ni: Papunen et al., 1977; Saltikoff et al., 2006; Makkonen et al., 2009). All Enontekiö samples are from the Sarvisoaivi area.

\subsection{Palaeoproterozoic Komatiites (Pulju and Karasjok Greenstone Belts)}

Palaeoproterozoic komatiites in the Pulju Greenstone Belt (Nilivaara and Hotinvaara areas: Figs. 1, 2) are part of the upper komatiite group, which Hanski et al. (2001) described as a komatiite-picrite association. The sampled komatiite units are associated with metapelites and sillimanite schists of the Mertavaara Formation, which overlie the quartzites of the Sietkuoja Formation (Fig. 2). Komatiite samples include thin flows $(<3 \mathrm{~m})$; massive cumulate bodies of unconstrained thickness; volcaniclastic units and flow units with visible fragmental flow top textures (samples \#44 to 56; Table A1). Nickel-sulphide mineralisation has been identified within the Hotinvaara sample area (1.3 Mt at $0.43 \%$ Ni: Papunen, 1998; Saltikoff et al., 2006; Makkonen et al., 2009).

Sampled komatiite lithologies from the Karasjok Greenstone Belt (samples \#75 to 94; Table A1) are from the Briittagielas Formation (Fig. 2). These komatiites are characterised by thin and pillowed flows with abundant fragmental and volcaniclastic units (Barnes \& Often, 1990). Ultramafic lithologies are intercalated with mafic volcanics and sedimentary lithologies (slate), with cross-cutting gabbroic units. Within the Karasjok Greenstone Belt there are no known occurrences of nickel-sulphide mineralisation.

\section{Materials and methods}

Samples from komatiite flow units comprise both A-zone (spinifex/flow top breccia) and B-zones (cumulate), as defined by Pyke et al. (1973). The samples contain no visible sulphides and do not display any primary igneous mineralogy. Samples were coarse crushed at The University of Western Australia using a jaw crusher, which was flushed with quartz, cleaned with a wire brush, acetone and blown dry with compressed air after each sample. Samples were sent to Ultra Trace Analytical Laboratories in Perth, Western Australia for further milling and geochemical analysis. Major and trace elements $\left(\mathrm{Al}_{2} \mathrm{O}_{3}, \mathrm{CaO}, \mathrm{Fe}_{2} \mathrm{O}_{3}, \mathrm{~K}_{2} \mathrm{O}, \mathrm{MgO}, \mathrm{MnO}, \mathrm{Na}_{2} \mathrm{O}\right.$, $\mathrm{P}_{2} \mathrm{O}_{5}, \mathrm{SiO}_{2}, \mathrm{TiO}_{2}, \mathrm{Cr}_{2} \mathrm{O}_{3}, \mathrm{SO}_{3}, \mathrm{Ni}, \mathrm{Cu}$ ) were analysed by wavelength dispersive X-Ray fluorescence (XRF) on $0.66 \mathrm{~g}$ samples, each fused to a glass bead. Platinum group elements $(\mathrm{Pt}, \mathrm{Pd}$, $\mathrm{Rh}, \mathrm{Ru}, \mathrm{Ir}$ ) were analysed by ICP-MS following a nickel-sulphide fire assay pre-concentration method, aqua regia dissolution of the sulphide button and co-precipitation of the PGE with tellurium from a $25 \mathrm{~g}$ sample. Total sulphur was measured by infrared adsorption during the combustion of the sample in an oxygen-rich environment.

The precision of the analytical methods was evaluated through the use of internal standards, blanks and duplicate analyses. Analytical precision was assessed with duplicate analyses by the method of Thompson and Howarth (1976). Major elements exhibit median errors between replicates of $<1 \%$ for measured concentrations. Chalcophile elements exhibit median errors of $17 \%$ Ir, $29 \% \mathrm{Ru}, 16 \%$ Rh, $18 \% \mathrm{Pt}, 13 \% \mathrm{Pd}, 1 \% \mathrm{Ni}$ and $21 \%$ for $\mathrm{Cu}$ over a normal unmineralised range of abundances. Duplicate analysis of all samples was carried out for select major elements utilizing ICP-OES (inductively coupled plasma-optical emission spectrometry). Concentrations of major and minor elements between the original and duplicate samples exhibit median variations of $2 \% \mathrm{TiO}_{2}, 1.5 \% \mathrm{Al}_{2} \mathrm{O}_{3}, 1.4$ $\% \mathrm{MgO}$, and $2.8 \% \mathrm{Ni}$.

\section{Whole-rock geochemistry results}

Whole-rock geochemical results for Archean komatiites from the Enontekiö area and Paleoproterozoic komatiites from the Karasjok and Pulju Greenstone Belts are shown in Table A1. 


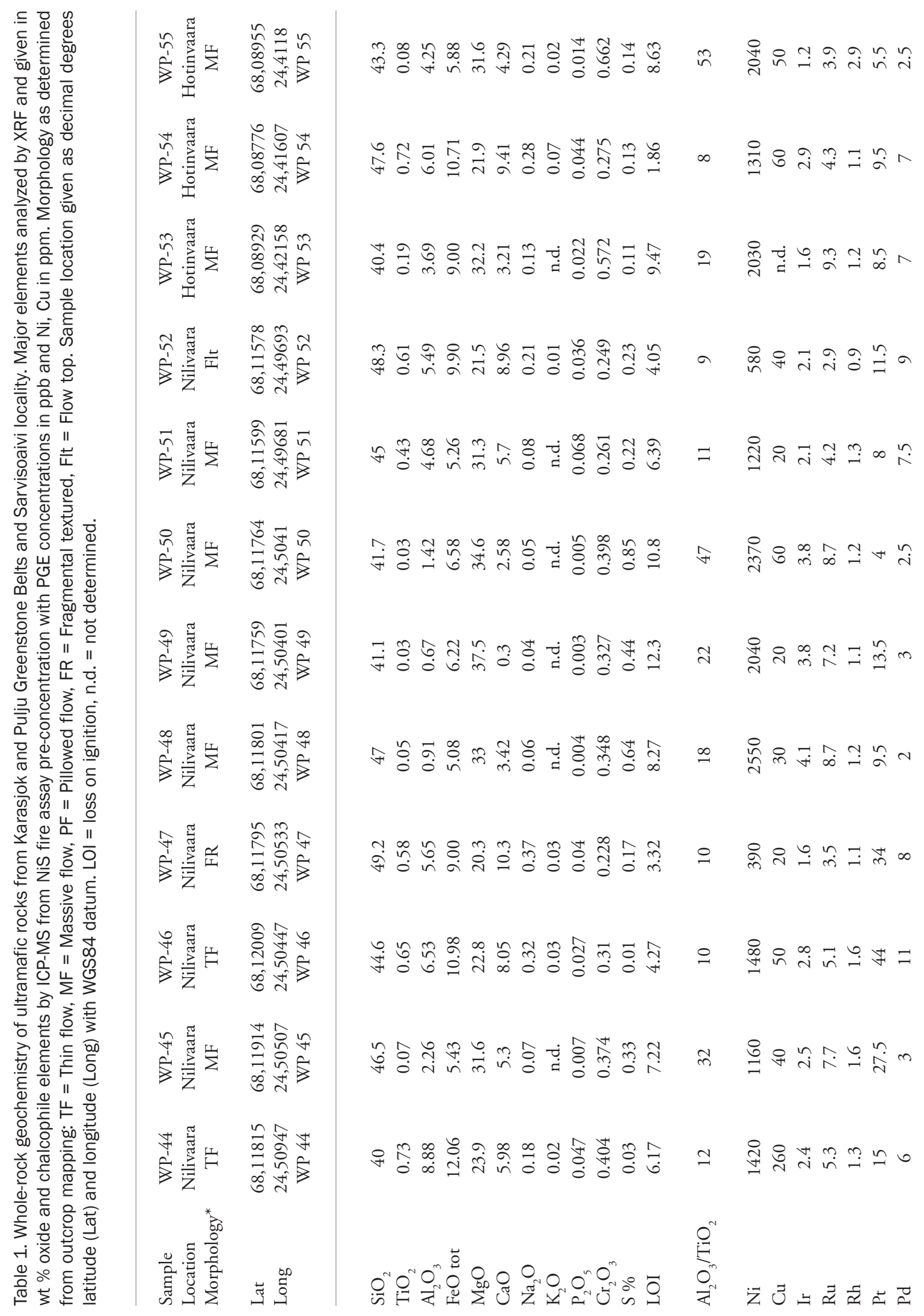




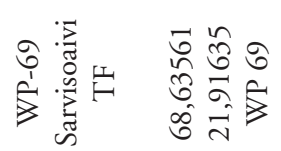

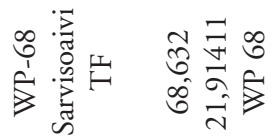

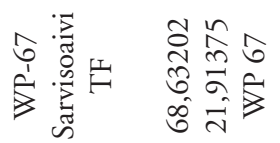

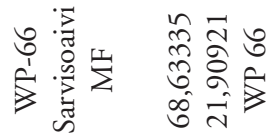

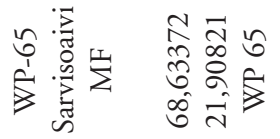

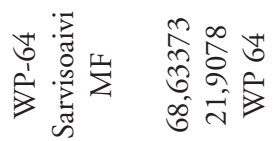

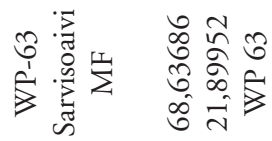

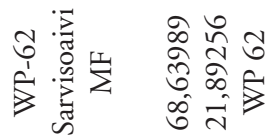

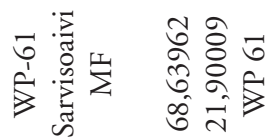

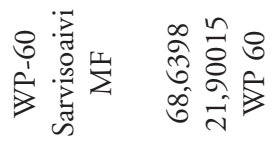

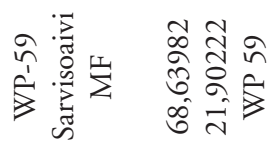

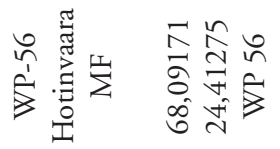

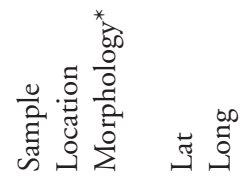

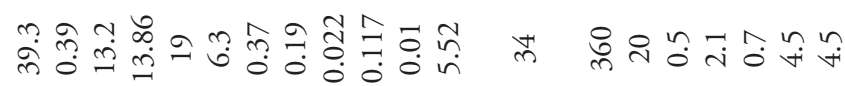

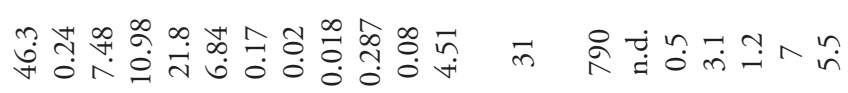

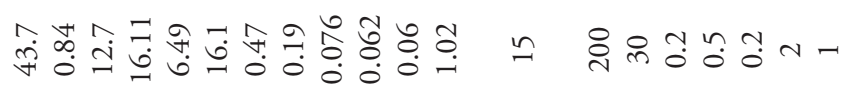

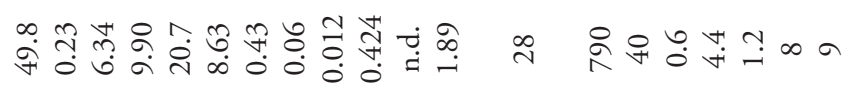

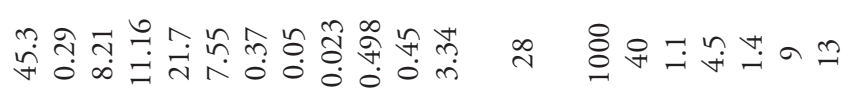

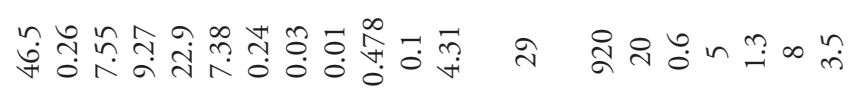

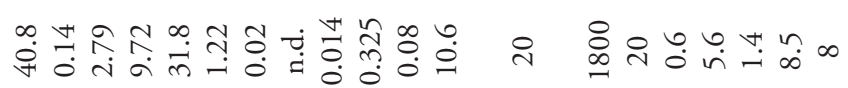

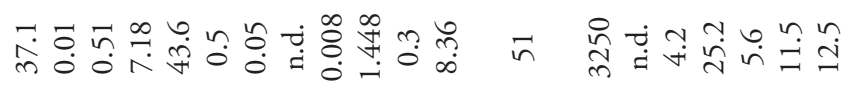

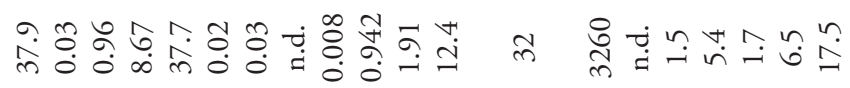

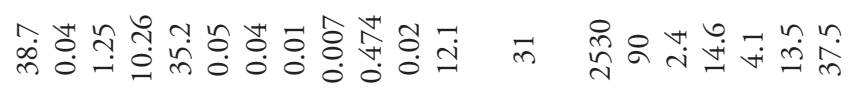


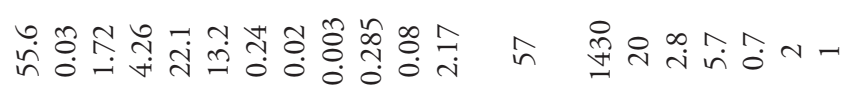
की 


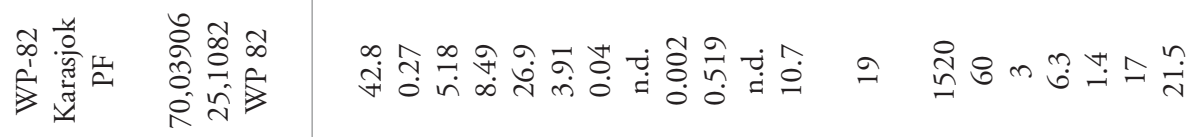

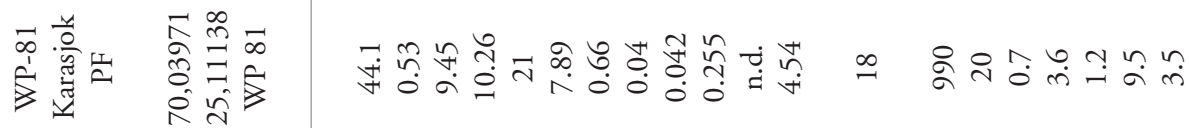

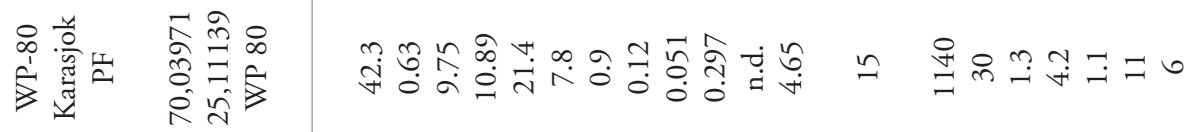

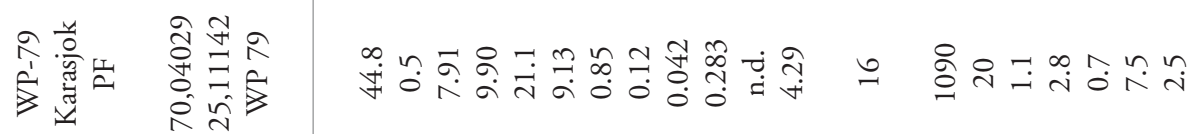

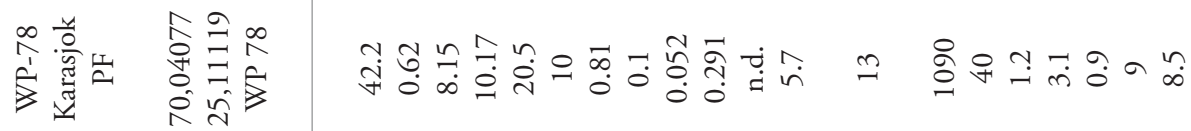

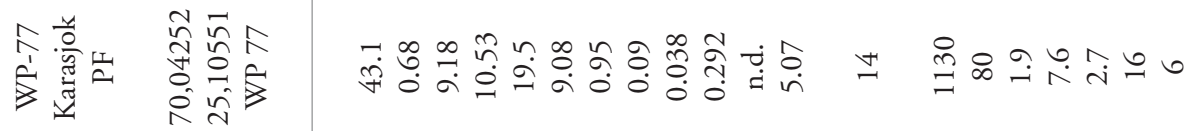

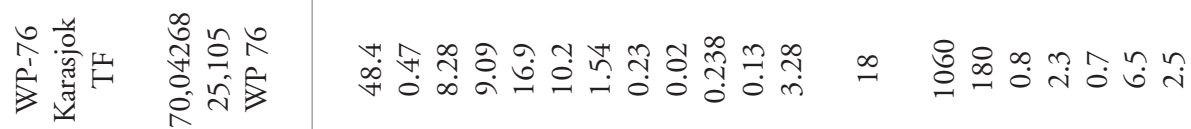

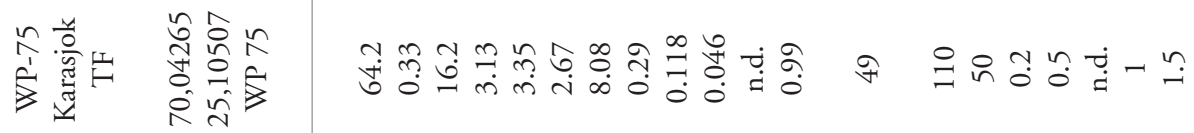

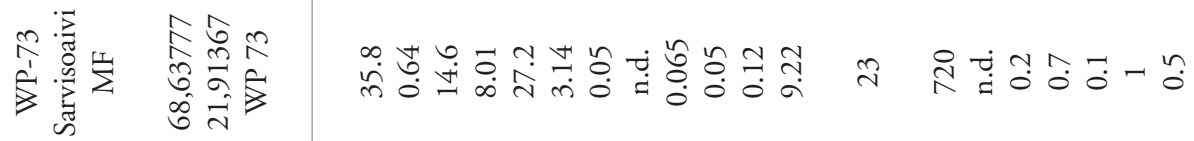

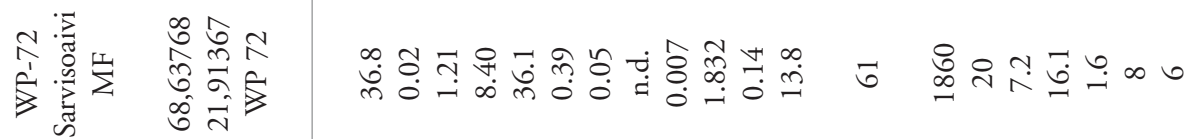

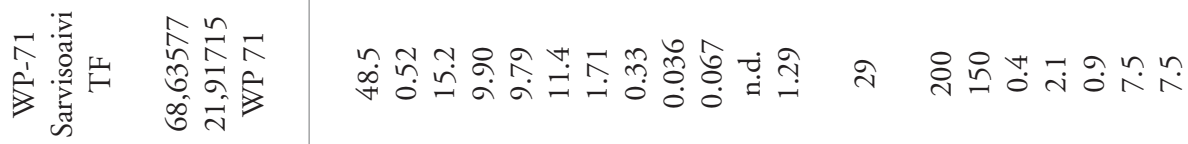

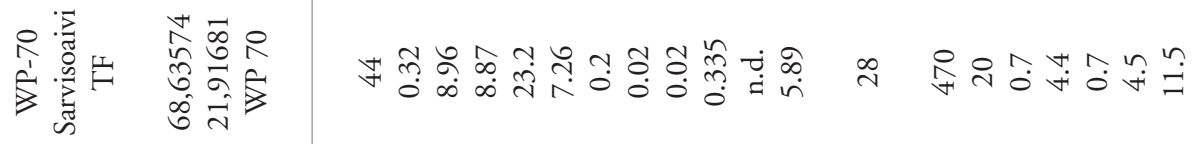

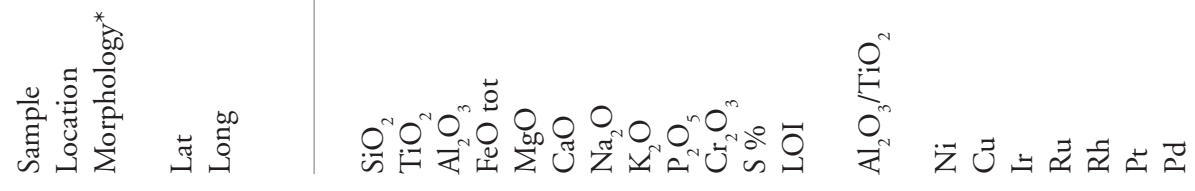


Table 1. continue ...

\begin{tabular}{|c|c|c|c|c|c|c|c|c|c|}
\hline Sample & WP-83 & WP-84 & WP-86 & WP-87 & WP-88 & WP-91 & WP-92 & WP-93 & WP-94 \\
\hline Location & Karasjok & Karasjok & Karasjok & Karasjok & Karasjok & Karasjok & Karasjok & Karasjok & Karasjok \\
\hline Morphology* & PF & PF & PF & FR & FR & TF & $\mathrm{TF}$ & TF & $\mathrm{TF}$ \\
\hline Lat & 70,03894 & 70,03227 & 70,03298 & 70,03309 & 70,03311 & 70,03085 & 70,03083 & 70,03083 & 70,03039 \\
\hline \multirow[t]{2}{*}{ Long } & 25,10805 & 25,12266 & 25,12109 & 25,12059 & 25,12051 & 25,07221 & 25,07203 & 25,07208 & 25,07303 \\
\hline & WP 83 & WP 84 & WP 86 & WP 87 & WP 88 & WP 91 & WP 92 & WP 93 & WP 94 \\
\hline $\mathrm{SiO}_{2}$ & 45.9 & 48.5 & 44 & 47.1 & 40.5 & 43.4 & 44.4 & 36.9 & 43.7 \\
\hline $\mathrm{TiO}_{2}$ & 0.62 & 0.45 & 1.19 & 0.52 & 0.72 & 1.26 & 1.07 & 3.42 & 1.36 \\
\hline $\mathrm{Al}_{2} \mathrm{O}_{3}$ & 10.5 & 7 & 13.4 & 6.59 & 11.9 & 8.4 & 7.43 & 10.3 & 7.01 \\
\hline $\mathrm{FeO}$ tot & 10.62 & 8.49 & 11.61 & 8.39 & 11.34 & 11.43 & 11.61 & 14.76 & 10.89 \\
\hline $\mathrm{MgO}$ & 16.1 & 20.4 & 13.5 & 22.1 & 20.8 & 20.1 & 20.8 & 17 & 20.1 \\
\hline $\mathrm{CaO}$ & 11.3 & 9.85 & 11.5 & 8.61 & 6.75 & 8.29 & 8.35 & 8.96 & 8.95 \\
\hline $\mathrm{Na}_{2} \mathrm{O}$ & 1.74 & 0.74 & 2 & 0.29 & 0.55 & 0.38 & 0.4 & 0.64 & 0.38 \\
\hline $\mathrm{K}_{2} \mathrm{O}$ & 0.08 & 0.05 & 0.25 & 0.02 & 0.04 & 0.04 & 0.05 & 0.1 & 0.04 \\
\hline $\mathrm{P}_{2} \mathrm{O}_{5}$ & 0.013 & 0.01 & 0.055 & 0.034 & 0.05 & 0.081 & 0.077 & 0.426 & 0.108 \\
\hline $\mathrm{Cr}_{2} \mathrm{O}_{3}$ & 0.253 & 0.292 & 0.163 & 0.365 & 0.288 & 0.248 & 0.214 & 0.005 & 0.261 \\
\hline S\% & n.d. & n.d. & 0.04 & n.d. & n.d. & n.d. & n.d. & n.d. & n.d. \\
\hline LOI & 1.37 & 3.08 & 0.79 & 4.84 & 5.53 & 4.8 & 3.98 & 5.26 & 5.76 \\
\hline $\mathrm{Al}_{2} \mathrm{O}_{3} / \mathrm{TiO}_{2}$ & 17 & 16 & 11 & 13 & 17 & 7 & 7 & 3 & 5 \\
\hline $\mathrm{Ni}$ & 800 & 950 & 350 & 1050 & 1060 & 840 & 1050 & 130 & 900 \\
\hline $\mathrm{Cu}$ & 20 & 20 & 110 & 60 & 20 & 300 & 70 & 20 & 50 \\
\hline Ir & 0.8 & 1.1 & 0.7 & 1.4 & 0.9 & 1.8 & 1.4 & 0.1 & 1.7 \\
\hline $\mathrm{Ru}$ & 3.6 & 3.7 & 2.5 & 2.8 & 3.4 & 3.8 & 3 & 0.5 & 4.1 \\
\hline $\mathrm{Rh}$ & 1.2 & 0.7 & 0.6 & 0.6 & 0.7 & 0.7 & 0.5 & n.d. & 1.1 \\
\hline $\mathrm{Pt}$ & 9.5 & 6.5 & 6 & 6.5 & 8 & 4.5 & 4 & 1 & 9.5 \\
\hline $\mathrm{Pd}$ & 2.5 & 2 & 3.5 & 4 & 1.5 & 4 & 3.5 & n.d. & 8 \\
\hline
\end{tabular}

\subsection{Archean Komatiites (Sarvisoaivi locality)}

Major elements from the komatiitic units of the Sarvisoaivi locality (60 km west of Enontekiö, Figure 1) exhibit a range of compositions reflecting olivine accumulation. Samples from thin flow units have median compositions of 17 wt \% MgO, 12 wt \% $\mathrm{FeO}_{\text {tor }}, 0.5$ wt $\% \mathrm{TiO}_{2}$, and 12 wt $\% \mathrm{Al}_{2} \mathrm{O}_{3}$, with massive units exhibiting a maximum $\mathrm{MgO}$ content of 48 wt \%. Negative correlations are observed between $\mathrm{MgO}$ and $\mathrm{TiO}_{2}$, and $\mathrm{MgO}$ and $\mathrm{Al}_{2} \mathrm{O}_{3}$. Positive correlations are documented between $\mathrm{MgO}$ and $\mathrm{Cr}$ (Fig. 3). $\mathrm{Al}_{2} \mathrm{O}_{3} / \mathrm{TiO}_{2}$ ratios are variable among different komatiite units, with a median value of 29 .

Chalcophile element concentrations exhibit a range from $<1 \mathrm{ppb}$ to a strong enrichment of 30 times primitive mantle (Table A1). Nickel exhibits a strong positive correlation with $\mathrm{MgO}$ (Fig. 3), whereas $\mathrm{Cu}$ does not exhibit any correlation (not shown). The platinum group elements exhibit poor positive correlation with $\mathrm{MgO}$ content (Fig. 4). In addition, Ir and Ru exhibit positive correlations with $\mathrm{MgO}$. The platinum group elements overall exhibit moderate positive inter-element correlations, with Ir exhibiting the poorest positive relationship. Additionally, the PGE correlate well with $\mathrm{Ni}$, whereas all the chalcophile elements correlate only moderately with $S$. 

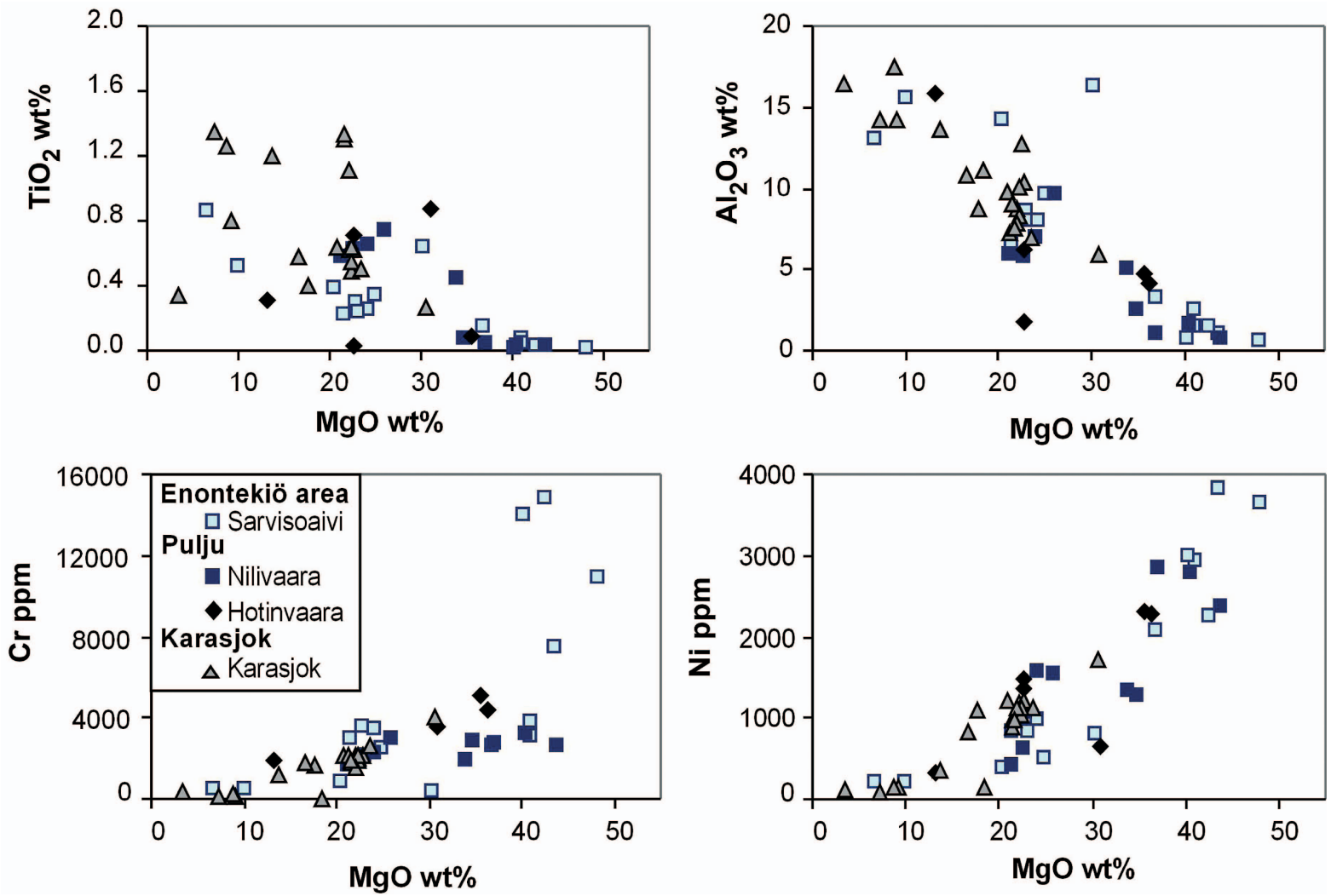

Fig. 3. Bivariant plots of major elements for the ultramafic units from the three areas from northern Finland and Norway, as determined by XRF and ICP-MS. Major element data are volatile-free. Komatiites from the Archean Enontekiö area (Sarvisoaivi), and Palaeoproterozoic areas: Karasjok (Karasjok Greenstone Belt), and Nilivaara and Hotinvaara (Pulju Greenstone Belt).

\subsection{Palaeoproterozoic Komatiites (Karasjok and Pulju Greenstone Belts)}

Komatiitic rocks from the Karasjok Greenstone Belt exhibit a range of $\mathrm{MgO}$ contents from 7 to $30 \mathrm{wt}$ $\%$. Samples from thin flows, pillowed flows and volcaniclastic units have median values of $20 \mathrm{wt} \%$ $\mathrm{MgO}, 11$ wt \% $\mathrm{FeO}_{\text {tot }}, 0.9$ wt $\% \mathrm{TiO}_{2}$, and $9.6 \mathrm{wt}$ $\% \mathrm{Al}_{2} \mathrm{O}_{3}$ (Table A1). Titanium oxide and $\mathrm{Al}_{2} \mathrm{O}_{3}$ exhibit negative correlations with $\mathrm{MgO}$, with $\mathrm{TiO}_{2}$ exhibiting more scatter (Fig. 3). The komatiitic rocks are characterised by a subchondritic $\mathrm{Al}_{2} \mathrm{O}_{3} / \mathrm{TiO}_{2}$ ratio of 13 .

Ultramafic rocks from the Pulju Greenstone Belt (Nilivaara and Hotinvaara areas) exhibit a range of $\mathrm{MgO}$ contents from 13 to 43 wt \%. Thin flows, pillowed flows and volcaniclastic rocks have median values of $23 \mathrm{wt} \% \mathrm{MgO}, 11 \mathrm{wt} \% \mathrm{FeO}_{\text {tot }}, 0.7 \mathrm{wt}$
$\% \mathrm{TiO}_{2}$, and $7.6 \mathrm{wt} \% \mathrm{Al}_{2} \mathrm{O}_{3}$ (Table A1). Negative correlations are observed between both $\mathrm{TiO}_{2}$ and $\mathrm{Al}_{2} \mathrm{O}_{3}$ with $\mathrm{MgO}$ (Fig. 3); the sampled units have a near- chondritic $\mathrm{Al}_{2} \mathrm{O}_{3} / \mathrm{TiO}_{2}$ ratio of 23 .

Within both Palaeoproterozoic greenstone belts, chromium abundances plot along the olivinechromium equilibrium cotectic line for units approximating liquid compositions (thin and pillowed flows, fragmental textured units and volcaniclastic units), whereas the massive units plot as olivine-chromite cumulates, as described by Barnes (1998). Komatiitic rocks in both greenstone belts exhibit elevated $\mathrm{TiO}_{2}$ contents (Karasjok komatiites: 0.9 wt \%, and Pulju komatiites: $0.7 \mathrm{wt}$ $\%)$ at a given $\mathrm{MgO}$ content, relative to Munro- and Barberton-type komatiite compositions (estimated 0.45 and $0.25 \mathrm{wt} \% \mathrm{TiO}_{2}$, respectively, for Karasjok and Pulju), as described by Barnes and Often (1990) and Hanski et al. (2001). 
Chalcophile element (Ni, Cu, Ir, Ru, Rh, Pt and $\mathrm{Pd}$ ) abundances within the sampled units are variable, ranging from below analytical detection limits $(<1 \mathrm{ppb})$ to enrichment of 3 to 5 times primitive mantle (Table A1). Nickel exhibits a strong positive correlation with $\mathrm{MgO}$, whereas $\mathrm{Cu}$ generally displays a negative relationship with moderate scatter
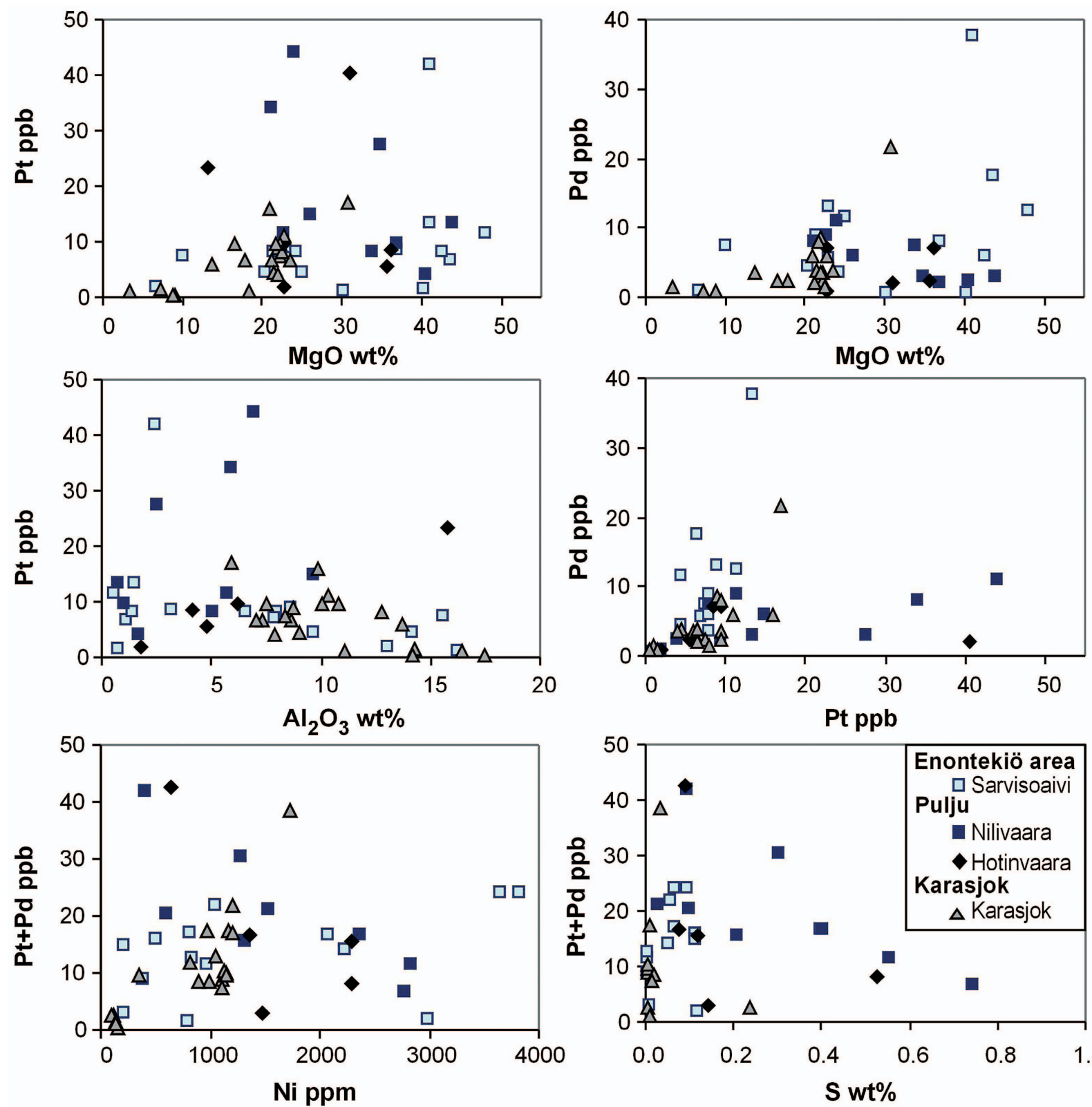

Fig. 4. Bivariant plots of chalcophile and major elements for the ultramafic units from the three areas in northern Finland and Norway, as determined by fire-assay ICP-MS. Komatiites from the Archean Enontekiö area (Sarvisoaivi) and Palaeoproterozoic areas: Karasjok (Karasjok Greenstone Belt), and Nilivaara and Hotinvaara (Pulju Greenstone Belt). 
negative correlations are observed in the Nilivaara samples, and positive correlations in the Karasjok samples (Fig. 4). The two remaining areas (Sarvisoaivi and Hotinvaara) exhibit no correlation. Beside a moderate negative correlation between $\mathrm{Pt}+\mathrm{Pd}$ and $\mathrm{S}$ at Nilivaara, sulphur does not correlate with any of the PGE (Fig. 4).

\section{Discussion}

The major and chalcophile element abundances obtained from whole-rock geochemistry provide insights into: 1) petrogenetic classification and initial chalcophile element content of the magma, 2) volcanic facies, and 3) presence of ore-forming geochemical signatures.

\subsection{Major Element Compositions and Petrogenetic Classification}

Samples collected from the Archean Enontekiö area are of Munro-type composition (Al-undepleted komatiites). This is based on the geochemical composition of interpreted quench-textured units with $\mathrm{MgO}$ contents $>18$ wt $\%$, and $\mathrm{Al}_{2} \mathrm{O}_{3} / \mathrm{TiO}_{2}$ ratios equal to or greater than chondritic, with a median value of 29. Data are plotted on the ultramafic discrimination diagram $\left[\mathrm{Al}_{2} \mathrm{O}_{3}\right]$ versus $\left[\mathrm{TiO}_{2}\right]$ of Hanski (1992), where the majority of samples are verified as Al-undepleted (Munro-type: Fig. 5), with a minor number of samples extending along the same trend line into the Al-depleted field (Barberton-type). However, the strong data scatter that is observable is most likely due to secondary alteration, which moderately affected all the studied rock samples.

Samples from the Palaeoproterozoic ultramafic units within the Karasjok Greenstone Belt (Briittagielas Formation) and the Pulju Greenstone Belt (Mertavaara Formation) exhibit a range of rock types (Fig. 5). Ultramafic units from the Karasjok Greenstone Belt exhibit a range of liquid compositions from $<18$ to 26 wt $\% \mathrm{MgO}$, with a median value of $20 \mathrm{wt} \% \mathrm{MgO}$. Despite samples from the Briittagielas Formation having a subchondritic $\mathrm{Al}_{2} \mathrm{O}_{3} / \mathrm{TiO}_{2}$ ratio (13), they mainly plot as Al-undepleted and exhibit a range from normal to Ti-enriched (Fig. 5). Hanski et al. (2001) observed this apparent disparity between whole-rock subchondritic $\mathrm{Al}_{2} \mathrm{O}_{3} / \mathrm{TiO}_{2}$ ratios and $\mathrm{Al}$-undepleted signatures in rocks from the Kittilä Greenstone Belt and attributed it to excess $\mathrm{TiO}_{2}$. As a result, ultramafic samples from the Briittagielas Formation of the Karasjok Greenstone Belt are interpreted as Al-

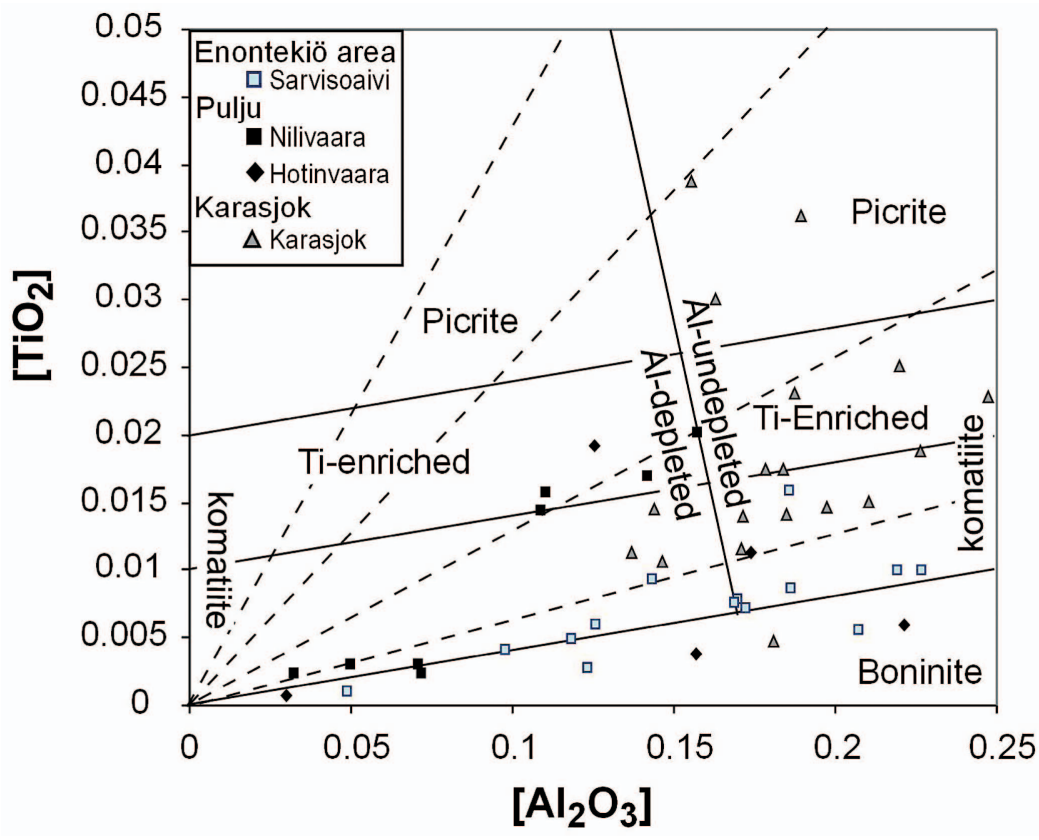

Fig. 5. $\left[\mathrm{Al}_{2} \mathrm{O}_{3}\right]$ versus $\left[\mathrm{TiO}_{2}\right]$ high-MgO volcanic discrimination diagram of Hanski et al. (2001). Where $\left[\mathrm{Al}_{2} \mathrm{O}_{3}\right]$ and $\left[\mathrm{TiO}_{2}\right]$ are normalized mole proportions using the equations $\left[\mathrm{Al}_{2} \mathrm{O}_{3}\right]=\mathrm{Al}_{2} \mathrm{O}_{3} /(2 / 3-\mathrm{MgO}-\mathrm{FeO})$ and $\left[\mathrm{TiO}_{2}\right]=\mathrm{TiO}_{2} /(2 / 3-\mathrm{MgO}-\mathrm{FeO}$ : see Hanski, 1992; Hanski et al., 2001). 
undepleted and Ti-enriched komatiites and picrites (Karasjok-type). This result is similar to that reported previously for the formation by Barnes and Often (1990), and similar to the ultramafic units within the Savukoski Group of the Kittilä Greenstone Belt (Fig. 2; Lehtonen et al., 1998; Hanski et al., 2001).

Komatiite samples from the Pulju Greenstone Belt (Mertavaara Formation) are characterised by a narrow range of liquid compositions with a median value of 23 wt $\% \mathrm{MgO}$. Although the majority of the samples have chondritic $\mathrm{Al}_{2} \mathrm{O}_{3} / \mathrm{TiO}_{2}$ ratios, they plot within the $\mathrm{Al}$-depleted field and exhibit both normal and enriched $\mathrm{TiO}_{2}$ abundances. Accordingly, the ultramafic units sampled within the Pulju Greenstone Belt are interpreted as Al-depleted Karasjoktype komatiites. This petrogenetic classification is similar to that reached by Papunen (1998), who identified the ultramafic rocks in the Pulju Greenstone Belt as Al-depleted.

In summary, despite being correlated within the Central Lapland Greenstone Belt (Fig. 2: Braathen \& Davidsen, 2000; Papunen, 1998; Lehtonen et al., 1998; Hanski et al., 2001), the Briittagielas and Mertavaara Formations, in the Karasjok and Pulju Greenstone Belts, respectively, exhibit differing geochemistry among ultramafic units. Titaniumenrichment is observed within the komatiitic units of both belts, and is characteristic of Karasjok-type komatiites (Barnes \& Often, 1990; Barley et al., 2000; Hanski et al 2001). However, the range of $\mathrm{Al}$ and $\mathrm{Mg}$ contents of inferred primary liquid compositions differs greatly: ultramafic units from the Karasjok Greenstone Belt exhibit a wide range of liquid compositions and are generally Alundepleted (Munro-type), whereas komatiite rocks of the Pulju Greenstone Belt display a narrow range of liquid compositions and are largely Al-depleted (Barberton-type).

\subsection{Volcanic Facies}

Volcanological studies on komatiite units associated with nickel-sulphide mineralisation have identified sustained magma flow-through within lava channels or conduits as a critical component for the ore- forming process (Lesher et al., 1984; Lesher \& Keays, 2002; Barnes, 2006a, 2006b; Barnes et al., 2004, 2007; Arndt et al., 2008). Favorable volcanic environments for mineralisation are recognised by the presence of thickened $(>30 \mathrm{~m}$ ) linear olivine mesocumulate to adcumulate bodies, interpreted to represent long-lived magma conduits within the larger developing flow field (Lesher et al., 1984; Hill et al., 1995). Barnes and Fiorentini (2012) advocate that the occurrence of a high proportion of olivine meso- and adcumulates within komatiite sequences, as is the case of the Kalgoorlie Terrane in the Yilgarn Craton of Western Australia, reflects the presence of a favourable lithospheric architecture that promotes high volume magma flux and transfer from the mantle to upper crustal levels.

Within the Enontekiö area (Sarvisoaivi locality), it is possible to observe the presence of both thin and thickened flow units, with orthocumulate and mesocumulate bodies of at least $5 \mathrm{~m}$ in thickness. Previous diamond drilling in the area indicates the presence of thickened olivine cumulate bodies (Papunen et al., 1977). These observations are supported by the whole-rock geochemistry, as apparent with $\mathrm{MgO}$ contents > 40 wt \% (Table A1). Field observations are corroborated by geochemical analyses that indicate presence of a cumulate olivine fraction with compositions more evolved than Fo90. Figure 6 indicates that the majority of thickened olivine cumulate bodies sampled in the area are channelised sheet flows to layered sills and lava lakes. Only one sample is classified as dunite (Fig. 6).

The volcanology of the Nilivaara and Hotinvaara areas within the Pulju Greenstone Belt comprises thin flows and thicker $(>5 \mathrm{~m})$ olivine cumulate units. Exploration diamond drilling in the Hotinvaara area identified dunitic units in excess of $100 \mathrm{~m}$ in thickness (Papunen, 1998), evident in the presence of samples with $\mathrm{MgO}>40$ wt \%. On the basis of the volcanic facies plots in Figure 6, it is possible to estimate olivine with $\mathrm{Fo}_{92-93}$ from the flow units to be in equilibrium with the initial magma composition. The remaining data plot below the defined fields, possibly due to $\mathrm{FeO}$ loss. If $\mathrm{FeO}$ loss occurred, the volcanological setting of these flows may have ranged from channelised sheet flows to 


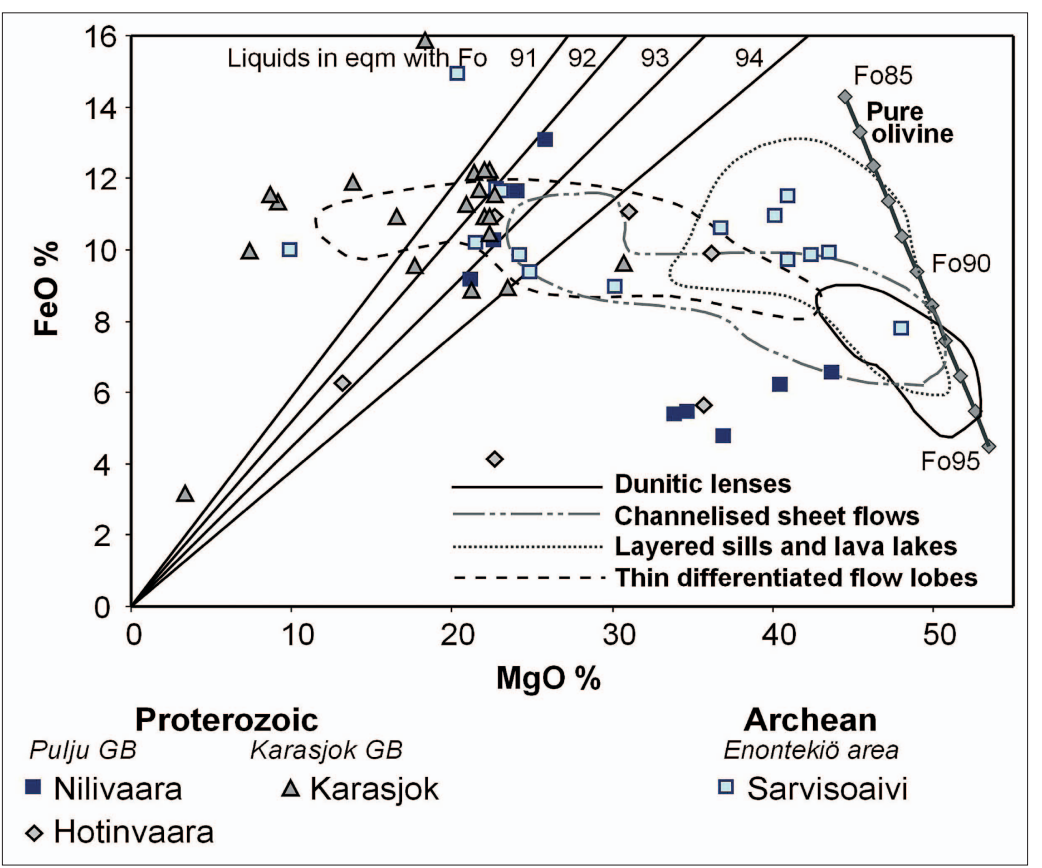

Fig. 6. $\mathrm{FeO}$ wt \% versus $\mathrm{MgO}$ wt \% recalculated to volatile free for ultramafic samples from the Karelian Craton. Olivine compositions in equilibrium with liquid shown as solid lines $\left(\mathrm{Fo}_{91-94}\right)$ and olivine compositions in adcumulates (pure olivine) shown as diamonds $\left(\mathrm{Fo}_{95-85}\right)$, with volcanic facies discrimination fields as determined by Barnes (2006a). layered sills, and lava lakes to dunitic units.

The Karasjok Greenstone Belt is characterised by pillowed and thin flows with variable abundance of volcaniclastic rocks and exhibits generally low $\mathrm{MgO}$ concentrations (maximum $30 \mathrm{wt} \%$ ). Samples are predominantly classified as thin differentiated flow lobes in equilibrium with a maximum olivine composition of $\mathrm{Fo}_{94}$, with a range extending to less than $\mathrm{Fo}_{90}$ (Fig. 6). A single sample (WP75) from the Karasjok area contained $3 \% \mathrm{MgO}$ and $65 \%$ $\mathrm{SiO}_{2}$, indicating either a felsic protolith or extensive silicification, and is excluded from the plots and discussion.

Sparse outcrop exposure in all sample areas limits the extent of volcanological interpretation. However, the use of volcanic facies differentiation tools based on major element abundances is able to aid the assessment of the volcanological setting. The volcanic facies interpretations carried out in this study are reconcilable with those that stemmed from more extensive diamond drilling carried out at Hotinvaara and Sarvisoaivi (Saltikoff et al., 2006; Makkonen et al., 2009).

In conclusion, the volcanological features reflected in major element geochemical signatures indicate that the Archean Enontekiö area and the
Pulju Greenstone Belt are prospective to host nickelsulphide mineralisation. In fact, these units display evidence of dynamic flow emplacement in high-flux channelized systems. Conversely, the volcanological setting of ultramafic rocks hosted within the Karasjok Greenstone Belt does not appear to be as prospective, due to presence of more stagnant and lower flux volcanic environment, where it is less likely that the magma could vigorously interact with supracrustal sulphide-bearing lithologies to form nickel-sulphide mineralisation.

\subsection{Chalcophile Element Signatures}

Mineralisation-related signatures are more apparent if silicate fractionation effects, most importantly the crystallisation of olivine, are eliminated. In order to do so, the strongly chalcophile elements $\mathrm{Pt}$ and $\mathrm{Pd}$ are normalised to incompatible elements such as $\mathrm{Ti}$, $\mathrm{Al}, \mathrm{Zr}$, or Y (Maier \& Barnes, 2005; Barnes et al., 2007; Fiorentini et al., 2010). Titanium is commonly utilised as the normalising factor (Barnes et al., 2007; Fiorentini, et al., 2010; Heggie, 2010) due to strong incompatibility in ultramafic systems, moderate abundance, good analytical precision and in- 
sensitivity to modification during crustal contamination. Previous work has confirmed that baseline values for $\mathrm{Pd} / \mathrm{Ti}$ and $\mathrm{Pt} / \mathrm{Ti}$ for 2.7 Ga Munro-type and 2.9 Ga Barberton-type komatiites are close to expected primitive mantle values, as a consequence of the incompatible behavior of $\mathrm{Pt}$ and Pd during sulphide-free komatiite petrogenesis and fractionation. (Fiorentini et al., 2010; Heggie, 2010). Fiorentini et al. (2010) demonstrated that strong positive correlations between ratios such as $\mathrm{Pt} / \mathrm{Ti}$, $\mathrm{Pd} / \mathrm{Ti}$ and $\mathrm{Rh} / \mathrm{Ti}$ are the hallmarks of sulphide fractionation or accumulation processes. However, the variable $\mathrm{TiO}_{2}$ abundance of Karasjok-type komatiites reflects the operation of source processes over and above the effects of olivine crystallisation, such that the assumption of initially primitive mantle Pt/Ti ratios in high degree partial melts can no longer be assumed to hold. Consequently, in this study $\mathrm{Al}_{2} \mathrm{O}_{3}$, which also exhibits negative correlations with $\mathrm{MgO}$ (Fig. 3), was used instead. Utilising this methodology (PGE/Al ${ }_{\mathrm{pmn}}$ : where the suffix pmn is primitive mantle-normalised), normal background concentrations should plot as a cluster of data points with PGE/Al ${ }_{p m n}$ close to 1 . The field for baseline Sundersaturated komatiites is shown in the centre of
Figure 7, along with the array of data points for mineralised komatiite units, confirming that almost identical relationships to those obtained by Fiorentini et al. (2010) are observed where $\mathrm{Al}$ rather than $\mathrm{Ti}$ is used as the normalizing element.

The komatiites of the Enontekiö area plot along the composite Barberton- and Munro-type trend (Fig. 7). The sample data exhibit variation in Pt$\mathrm{Pd} / \mathrm{Al}_{\mathrm{pmn}}$ values from $<0.1$ to 40 (Fig. 7) and plot in the fields of PGE-Enriched, PGE-Depleted and Normal-PGE (cf. Heggie et al., 2012). Consequently, the samples collected from surface outcrops in the Enontekiö area indicate that the komatiites here were sulphide liquid saturated, and hence indicate high prospectivity to host nickel-sulphide mineralisation. This interpretation is supported by evidence from exploration diamond drilling and the delineation of nickel-sulphide mineralisation within the Sarvisoaivi area (0.7 Mt at $0.4 \%$ Ni: Papunen et al., 1977; Saltikoff et al., 2006).

Palaeoproterozoic komatiitic units within the Karasjok sampling locality are Ti-enriched, Alundepleted and exhibit a range of $\mathrm{Pt} / \mathrm{Al}_{\mathrm{pmn}}$ and $\mathrm{Pd} /$ $\mathrm{Al}_{\text {pmn }}$ values from 0.01 to 1 (Fig. 7). About a third of samples plot within the sulphide-free (sulphide

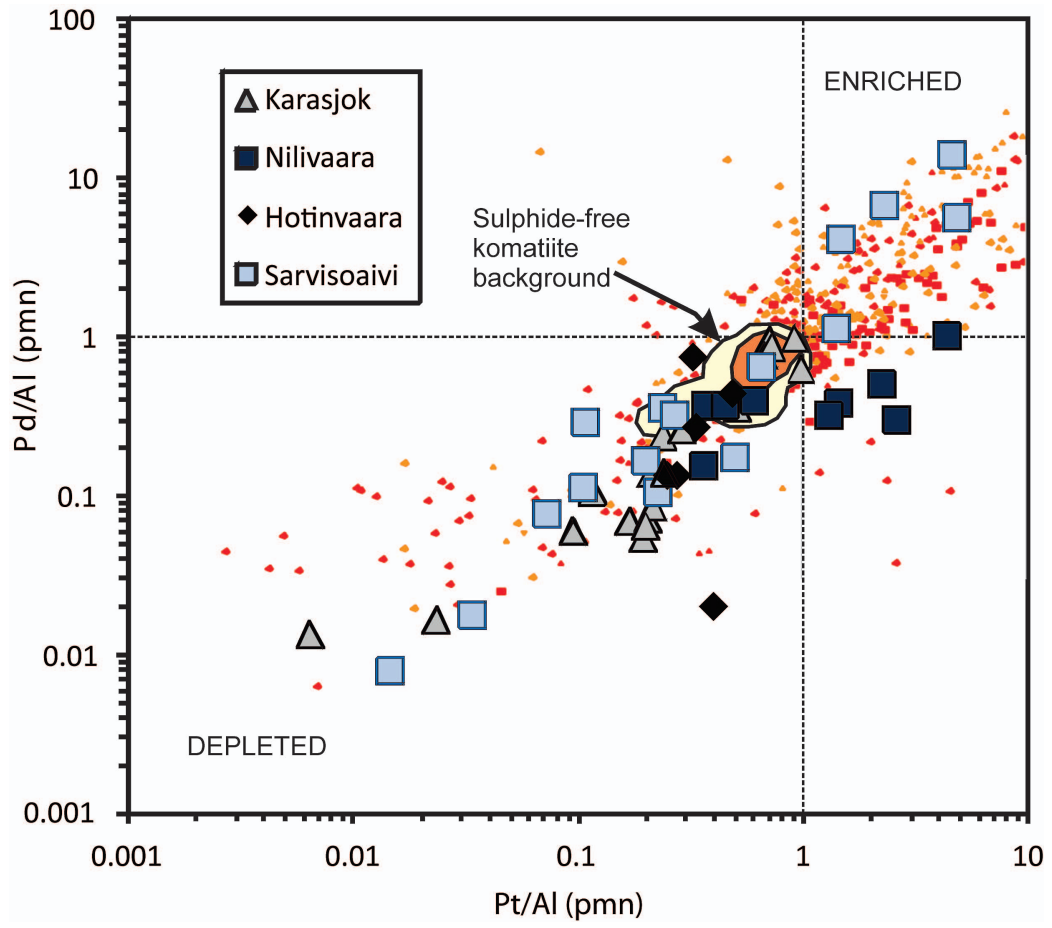

Fig. 7. $\mathrm{Pt} / \mathrm{Al}_{\mathrm{pmn}}$ versus $\mathrm{Pd} / \mathrm{Al}_{\mathrm{pmn}}$ diagram for identification of sulphide-related platinum-group element depletion and enrichment within komatiitic systems showing samples from this study against global database of Fiorentini et al. (2010). Yellow/orange shaded area indicates $50^{\text {th }}$ and $80^{\text {th }}$ percentiles on data density for samples of komatiites from unmineralised sequences. Small red and orange symbols are individual samples of sulphide-poor komatiite rocks from host units to major (red) and minor (orange) komatiite-hosted nickel sulphide deposits, Munro-type and Barberton-type komatiites from belts younger than $3.0 \mathrm{Ga}$. 
unsaturated) field, and the remainder are variably depleted in both Pt and Pd. Mineralisation is not documented in the sample area or within the Karasjok Greenstone Belt. However, the PGE/Al ${ }_{\text {pmn }}$ ore-forming signatures documented in this study, together with the occurrence of values plotting in the Normal-PGE field, support the hypothesis that a significant proportion of komatiite units in the Karasjok Greenstone Belt had attained sulphide saturation prior to emplacement.

Komatiite units in the Pulju Greenstone Belt at Nilivaara and Hotinvaara are Al-depleted Karasjoktype and exhibit a relatively restricted $\mathrm{Pt} / \mathrm{Al}_{\mathrm{pmn}}$ and $\mathrm{Pd} / \mathrm{Al}_{\mathrm{pmn}}$ range. Values of $\mathrm{Pt} / \mathrm{Al}_{\mathrm{pmn}}$ plot either within the background range or up to a factor of 5 higher, but there is no significant correlation with $\mathrm{Pd} / \mathrm{Al}_{\text {pmn' }}$, which ranges from 1 to 0.1 , with a single outlier from Nilivaara at 0.02 , indicating moderate degrees of depletion. Low-grade mineralisation has been identified within the Hotinvaara area (1.3 Mt at 0.43 \% Ni: Papunen, 1998; Saltikoff et al., 2006), consistent with the presence of Pt-enriched and Pddepleted samples but evidently not reflected in Pd enrichment.

The Pt and Pd signatures observed at the Sarvisoaivi and Karasjok localities are correlated with one another, and consistent with a simple model of coupled enrichment and depletion in Pt and Pd due to sulphide liquid extraction (at Karasjok) and both extraction and accumulation at Sarvisoaivi. However, the Pulju belt samples from Nilivaara and Hotinvaara display more complex behaviour and complete decoupling of Pt from Pd. The Nilivaara suite in particular shows about a 15 fold variation in $\mathrm{Pt} / \mathrm{Al}_{\mathrm{pmn}}$ for a 5 fold variation in $\mathrm{Pt} / \mathrm{Al}_{\mathrm{pmn} \text {. }}$ Furthermore, the samples enriched in Pt relative to normalised mantle background are depleted in Pd. This decoupling may be consequence of differential hydrothermal mobility of $\mathrm{Pt}$ from $\mathrm{Pd}$ during alteration, but this is considered to be an unlikely explanation in that it is not observed at the other localities, where the ratios correlate strongly, and also on evidence from komatiites elsewhere that $\mathrm{Pt}$ and $\mathrm{Pd}$ are characteristically highly immobile in sulphide-poor environments (Barnes \& Liu, 2012). An alternative explanation is that $\mathrm{Pt}$ and $\mathrm{Pd}$ may have been decoupled owing to direct precipitation and accumulation of a liquidus Pt-rich alloy or arsenide phase; this has not been previously demonstrated in komatiites, other than in massive sulphide orebodies (e.g. Godel et al., 2012), but there is mounting evidence from non-komatiitic environments for high-temperature magmatic precipitation of Pt-rich phases in association with disseminated sulphides (e.g. Ballhaus \& Sylvester, 2000; Barnes et al., 2011; Godel et al., 2010).

Normalising Pt and Pd abundances to incompatible elements is intended to remove variance due to olivine control, such that in theory there should be no systematic relationship between normalised abundances and whole rock $\mathrm{MgO}$ content. However, when plotted against $\mathrm{MgO}$, there is an apparent correlation between $\mathrm{Pt} / \mathrm{Al}$ and $\mathrm{Pd} / \mathrm{Al}$ with $\mathrm{MgO}$ (Fig. 8). On close inspection this relationship is entirely accounted for by the Karasjok and Sarvisoaivi samples, and is not present in the Pulju belt samples (Nilivaara, Hotinvaara). The $\mathrm{MgO}$ variance is made up of two components: cumulus olivine content, accounting for $\mathrm{MgO}$ values above about $25 \% \mathrm{MgO}$, and the degree of fractionation of samples thought to represent liquids at $\mathrm{MgO}<25 \%$. The cumulate samples at Karasjok have mantle normalised $\mathrm{Pt} / \mathrm{Al}$ and $\mathrm{Pd} / \mathrm{Al}$ close to 1 , while progressively more depleted signatures are seen in progressively more evolved liquids, implying that this signature may reflect cotectic sulphide liquid segregation during olivine fractionation. This process typically does not produce ore-grade mineralisation, as the cotectic proportion of sulfide to olivine is too low (Barnes, 2007). The same may be true of the Sarvisoaivi suite, although here there is evidence of sulphide accumulation within the cumulate rocks, and a single strongly $\mathrm{Pt}$ and $\mathrm{Pd}$ depleted sample at $30 \% \mathrm{MgO}$. On this basis, the Sarvisoaivi suite evidently has the highest potential for nickel sulphide mineralisation of the localities investigated.

\section{Conclusions}

Komatiites in northern Finland and Norway are diverse in both age (Archean and Palaeoproterozoic) 

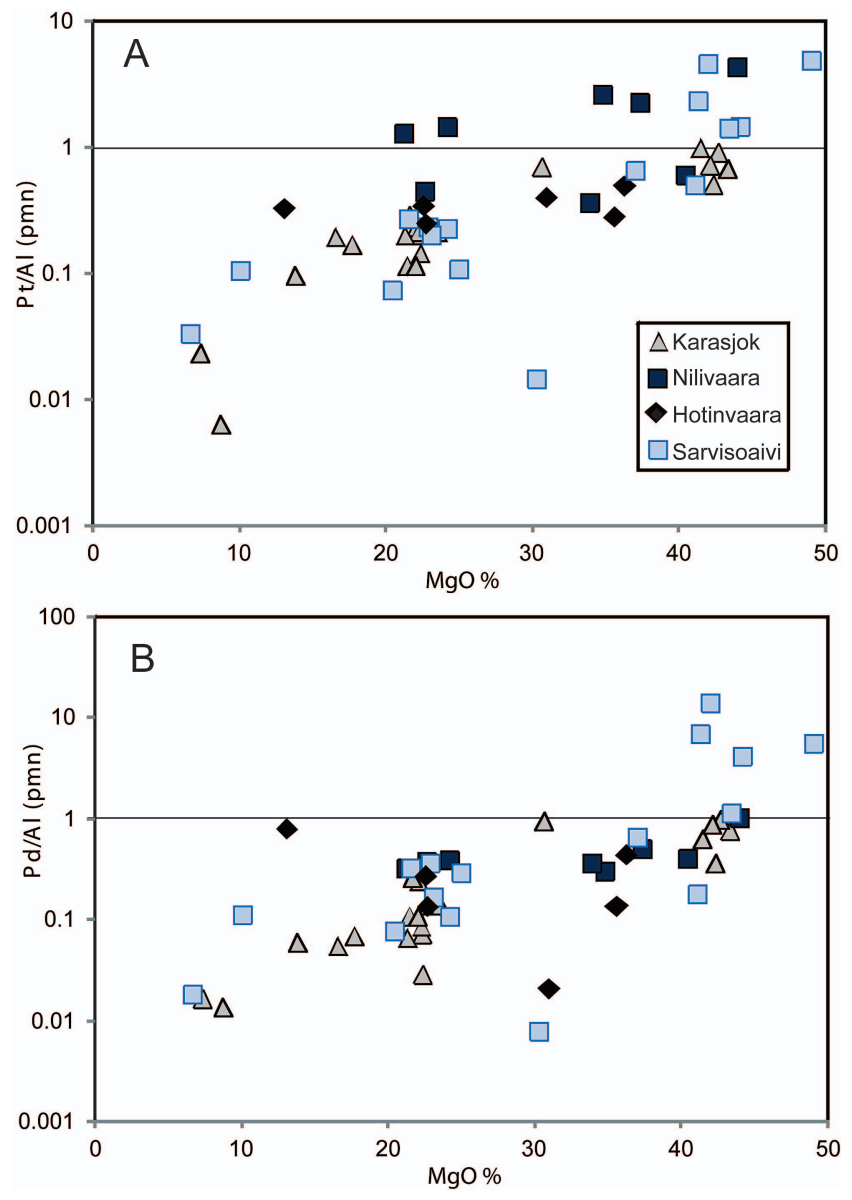

Fig. 8. $\mathrm{Pt} / \mathrm{Al}_{\mathrm{pmn}}$ and $\mathrm{Pd} / \mathrm{Al}_{\mathrm{pmn}}$ vs $\mathrm{MgO}$ (weight \% anhydrous) for samples from study areas.

and geochemical type, comprising both Munro- and Karasjok-types. Within the sampled areas, cumulate bodies were prevalently identified in the Enontekiö area and Pulju Greenstone Belt, whereas thin and pillowed flow sequences dominate the Karasjok Greenstone Belt. Consequently, from a broad volcanological perspective, the presence of cumulates makes the Enontekiö area and Pulju Greenstone Belt more prospective than the Karasjok Greenstone Belt.

The chalcophile element signature of a limited number of samples from Archean Munro-type komatiites in the Sarvisoaivi locality indicates that these units have mineralisation potential (Fig. 7). This inference is warranted by the discovery of nickel-sulphide mineralisation in the Sarvisoaivi locality (Papunen et al., 1977; Saltikoff et al., 2006;
Makkonen et al., 2009). However, this study did not identify systematic PGE anomalism in unmineralised samples from the Pulju Greenstone Belt, despite the fact that nickel-sulphide mineralisation has been identified at Hotinvaara (Papunen, 1998; Saltikoff et al., 2006; Makkonen et al., 2009). Although nickelsulphide mineralisation has not yet been identified within the Karasjok Greenstone Belt, the chalcophile element mineralisation indicators generated in this study indicate that the more evolved komatiitic magmas underwent sulphide liquid fractionation, probably of cotectic origin during progressive fractionation as indicated by a correlation between degree of PGE depletion and MgO. Nonetheless, the Karasjok sequence should be regarded as potentially prospective. So far only flank-facies thin flows have been sampled. Exploration efforts should therefore be focused in the identification of high-volume flow conduits and channels within the large volcanic flow field.

\section{Acknowledgements}

This research was supported by a 2007 Society of Economic Geologists Foundation Inc. student research grant (Hickok-Radford Memorial Fund) to G. Heggie.

The research forms part of a larger project with AMIRA (AMIRA P710A), including BHP Billiton, Independence Group and Noril'sk Nickel Australia as company sponsors. The authors are grateful for their support. A previous version of the manuscript greatly benefited from the insightful and thorough reviews of Peter Lightfoot, Tapio Halkoaho, Martin Prendergast and Mei-Fu Zhou. We are grateful to Eero Hanski, Hannu Makkonen and Igor Puchtel for their insightful comments. Finally, we thank Jukka Jokela for his guidance and logistical support during an extensive sampling trip in the field. This is contribution 365 from the ARC Centre of Excellence for Core to Crust Fluid Systems (http://www.ccfs.mq.edu.au).

\section{References}

Arndt, N.T., Barnes, S.J. \& Lesher, C.M. 2008. Komatiite. University Press, Cambridge. 467 p.

Ballhaus, C. \& Sylvester, P. 2000. Noble metal enrichment processes in the Merensky Reef, Bushveld Complex. Journal of Petrology 41, 545-561. 
Barley, M.E., Kerrich, R., Reudavy, I. \& Xie, Q. 2000. Late Archean Ti-rich, Al-depleted komatiites and komatiitic volcaniclastic rocks from the Murchison Terrane in Western Australia. Australian Journal of Earth Sciences 47, 873-883.

Barnes, S.-J., Naldrett, A.J. \& Gordon, M.P. 1985. The origin of the fractionation of platinum-group elements in terrestrial magmas. Chemical Geology 53, 303-323.

Barnes, S.-J. \& Often, M. 1990. Ti-rich komatiites from northern Norway. Contributions to Mineralogy and Petrology 105, 42-54.

Barnes, S.J. 1998. Chromite in komatiites, I. Magmatic controls on crystallization and composition. Journal of Petrology 39, 1689-1720

Barnes, S.J. 2006a. Komatiites: Petrology, Volcanology, Metamorphism, and Geochemistry. In: Barnes, S.J. (ed.) Nickel Deposits of the Yilgarn Craton: Geology, Geochemistry, and Geophysics Applied to Exploration. Society of Economic Geologists, Special Publication 13, $13-50$.

Barnes, S.J. 2006b. Komatiite-hosted nickel sulphide deposits: Geology, Geochemistry, and Genesis. In: Barnes, S.J. (ed.) Nickel Deposits of the Yilgarn Craton: Geology, Geochemistry, and Geophysics Applied to Exploration. Society of Economic Geologists, Special Publication 13, 51-118.

Barnes, S.J. 2007. Cotectic precipitation of olivine and sulfide liquid from komatiite magma, and the origin of komatiitehosted disseminated nickel sulfide mineralization at $\mathrm{Mt}$ Keith and Yakabindie, Western Australia. Economic Geology 102, 299-304.

Barnes, S.J., Hill, R.E.T., Perring, C.S. \& Dowling, S.E. 2004. Lithogeochemical exploration for komatiite-associated Nisulphide deposits: strategies and limitations. Mineralogy and Petrology 82, 259-293.

Barnes, S.J., Lesher, C.M. \& Sproule, R.A. 2007. Geochemistry of komatiites in the Eastern Goldfields Superterrane, Western Australia, and the Abitibi Greenstone Belt, Canada, and implications for the distribution of associated Ni-Cu-PGE deposits: Applied Earth Science 116, 167187.

Barnes, S.J., Osborne, G. A., Cook, D., Barnes, L., Maier, W. D. \& Godel, B. M. 2011. The Santa Rita Nickel Sulfide Deposit in the Fazenda Mirabela Intrusion, Bahia, Brazil: geology, sulfide geochemistry and genesis. Economic Geology 106, 1083-1110.

Barnes, S.J. \& Fiorentini, M.L. 2012. Komatiite magmas and Ni sulphide deposits: a comparison of variably endowed Archean terranes. Economic Geology 107, 755-780.

Barnes, S.J. \& Liu, W. 2012. Pt and Pd mobility in hydrothermal fluids: evidence from komatiites and from thermodynamic modeling. Ore Geology Reviews 44, 4958.

Barnes, S.J., Heggie, G.J. \& Fiorentini, M.L. 2013. Spatial variation in platinum group element concentrations in ore-bearing komatiite at the Long-Victor deposit, Kambalda Dome, Western Australia: enlarging the footprint of nickel sulfide orebodies. Economic Geology 108, 913-933.

Braathen, A. \& Davisen, B. 2000. Structure and stratigraphy of the Palaeoproterozoic Karasjok Greenstone Belt, northern Norway - regional implications. Norsk Geologist Tidsskrift 80, 33-50.

Fiorentini, M.L., Beresford, S.W., Deloule, E., Hanski, E., Stone, W.E. \& Pearson, N.J. 2008. The role of mantle-derived volatiles in the petrogenesis of Palaeoproterozoic ferropicrites in the Pechenga Greenstone Belt, northwestern Russia: Insights from in-situ microbeam and nanobeam analysis of hydromagmatic amphibole. Earth and Planetary Sciences 268, 2-14.

Fiorentini, M.L., Barnes, S.J., Lesher, C.M., Heggie, G., Keays, R.R. \& Burnham, O.M. 2010. Platinum-group element geochemistry of mineralized and non-mineralized komatiites and basalts. Economic Geology 105, 795-823.

Fiorentini, M.L., Barnes, S.J., Maier, W.D., Burnham, O.M. \& Heggie, G.J. 2011. Global variability in the platinumgroup element contents of komatiites. Journal of Petrology 52, 83-112.

Gaál, G. \& Gorbatschev, R. 1987. An outline of the Precambrian evolution of the Baltic Shield. Precambrian Research 35, 15-52.

Gangopadhyay, A., Walker, R.J., Hanski, E. \& Solheid, P.A. 2006. Origin of Paleoproterozoic Komatiites at Jeesiö, Kittilä Greenstone Complex, Finnish Lapland. Journal of Petrology 47, 773-789.

Godel, B.M., Barnes, S.J., Barnes, S.-J. \& Maier, W.D. 2010. Platinum ore in 3D: Insights from high-resolution X-ray computed tomography. Geology 38, 1127-1130.

Godel, B.M., Gonzalez-Alvarez, I., Barnes, S.J., Barnes, S.-J., Parker, P. \& Day, J. 2012. Sulfides and sulfarsenides from the Rosie nickel prospect, Duketon greenstone belt, Western Australia. Economic Geology 107, 275-294.

Gorbunov, G.I., Yakovlev, Yu.N., Goncharov, Yu.V., Gorelov, V.A. \& Telnov, V.A. 1985. The nickel areas of the Kola Peninsula. In: Papunen, E. \& Gorbunov, G.I. (Eds.) Nickel-Copper Deposits of the Baltic Shield and Scandinavian Caledonides. Geological Survey of Finland, Bulletin 333, 17-41.

Hanski, E.J. 1992. Petrology of the Pechenga ferropicrites and cogenetic Ni-bearing gabbro-wehrlite intrusions, Kola Peninsula, Russia. Geological Survey of Finland, Bulletin 367, 1-192.

Hanski, E.J., Huhma, H., Lehtonen, M.I. \& Rastas, P. 1997. Isotopic (Sm-Nd, U-Pb) and geochemical evidence for an oceanic crust to molasses evolution of the Paleoproterozoic Kittilä greenstone complex, northern Finland. COPENA conference at NGU, August 18-22, 1997, Abstracts and Proceedings, NGU Report 97, p. 131. 
Hanski, E.J., Huhma, H., Rastas, P. \& Kamenetsky, V.S. 2001. The Paleoproterozoic komatiite-picrite association of Finnish Lapland. Journal of Petrology 42, 855-876.

Hanski, E. \& Huhma, H. 2005. Central Lapland greenstone belt, In: Lehtinen, M., Nurmi, P.A., \& Rämö O.T. (eds.) Precambrian Geology of Finland - Key to the Evolution of the Fennoscandian Shield. Elsevier, Amsterdam, pp. 139-194.

Heggie, G.J. 2010. The Application of platinum group elements in komatiite-hosted nickel sulphide exploration. Unpublished PhD thesis, University of Western Australia. $350 \mathrm{p}$.

Heggie, G.J., Fiorentini, M.L., Barnes, S.J. \& Barley, M.E. 2012a. Maggie Hays nickel deposit: Part 1. Stratigraphic control on the style of komatiite emplacement in the 2.9 Ga Lake Johnston Greenstone Belt, Yilgarn Craton, Western Australia. Economic Geology 107, 797-816.

Heggie, G.J., Fiorentini, M.L., Barnes, S.J. \& Barley, M.E. 2012b. Maggie Hays nickel deposit: Part 2. Ore forming process in an intrusive komatiite system: Examination of the spatial distribution of PGE in the Maggie Hays NiSystem, Lake Johnston Greenstone Belt, Western Australia. Economic Geology 107, 817-833.

Hill, R.E.T., Barnes, S.J., Gole, M.J. \& Dowling, S.E. 1995. The volcanology of komatiites as deduced from field relationships in the Norseman-Wiluna greenstone belt, Western Australia. Lithos 34, 159-188.

Hronsky, J.M.A. \& Schodde, R.C. 2006. Nickel Exploration history of the Yilgarn Craton: From Nickel boom to today. In: Barnes, S.J. (ed.) Nickel Deposits of the Yilgarn Craton: Geology, Geochemistry, and Geophysics applied to exploration. Society of Economic Geologists, Special publication 13, 1-12.

Kayryak, A.I. \& Morozov, S.A. 1985. The Ni area of the Vetreny belt of Karelia. Geological Survey of Finland, Bulletin 333, 109-121.

Keays, R.R. 1982. Palladium and iridium in komatiites and associated rocks: application to petrogenetic problems. In: Arndt, N.T. \& Nisbet, E.G. (eds.) Komatiites. London,
Allen and Unwin, pp. 435-457.

Kröner, A., Puustinen, K. \& Hickman, M. 1981. Geochronology of an Archean Gneiss Dome in Northern Finland and its relation with an unusual overlying volcanic conglomerate and komatiitic greenstone. Contributions to Mineralogy and Petrology 76, 33-41.

Kurki, J. \& Papunen, H. 1985. Geology and nickel-copper deposits of the Kianta area, Suomussalmi. In Papunen, H. \& Gorbounov, G.I. (eds.) Nickel-copper deposits of the Baltic Shield and Scandinavian Caledonides. Geological Survey of Finland, Bulletin 333, 155-161.

Lahtinen, R., Korja, A. \& Nironen, M. 2005. Paleoproterozoic tectonic evolution. In: Lehtinen, M., Nurmi, P.A. \& Rämö O.T. (eds.) Precambrian Geology of Finland - Key to the Evolution of the Fennoscandian Shield. Elsevier, Amsterdam, pp. 669-680.

Lahtinen, R., Korja, A., Nironen, M. \& Heikkinen, P. 2009. Palaeoproterozoic accretionary processes in Fennoscandia. Geological Society, London, Special Publications 318, 237-256.

Lehtonen, M., Airo, M-L., Eilu, P., Hanski, E., Kortelainen, V., Lanne, E., Manninen, T., Rastas, P., Räsänen, J.J. \& Virronsalo, P. 1998. The stratigraphy, petrology and geochemistry of the Kittilä greenstone area, northern Finland. Geological Survey of Finland, Report of Investigations 140, 1-144.

Lesher, C.M., Arndt, N.T. \& Groves, D.I. 1984. Genesis of komatiite-associated nickel sulphide deposits at Kambalda, Western Australia: a distal volcanic model. In: Buchanan, D.L. \& Jones, M.J. (eds.) Sulphide deposits in mafic and ultramafic rocks. Institute of Mining and Metallurgy, London, pp. 55-61.

Lesher, C.M. \& Keays, R.R. 2002. Komatiite-associated NiCu-PGE deposits: Geology, Mineralogy, Geochemistry, and Genesis. In: Cabri, L.J. (ed.) The Geology, Geochemistry, Mineralogy and Mineral Beneficiation of Platinum-Group Elements. Canadian Institute of Mining, Metallurgy and Petroleum, Special Volume 54, 579-617. 